\title{
Risk assessment of peak exposure to genotoxic carcinogens
}

$5688-\mathrm{V}$

$\mathrm{H}$ Verhagen

VJ Feron

$\mathrm{PW}$ van Vliet

Gezondheidsraad

$>$
0
$\stackrel{8}{\circ}$
+

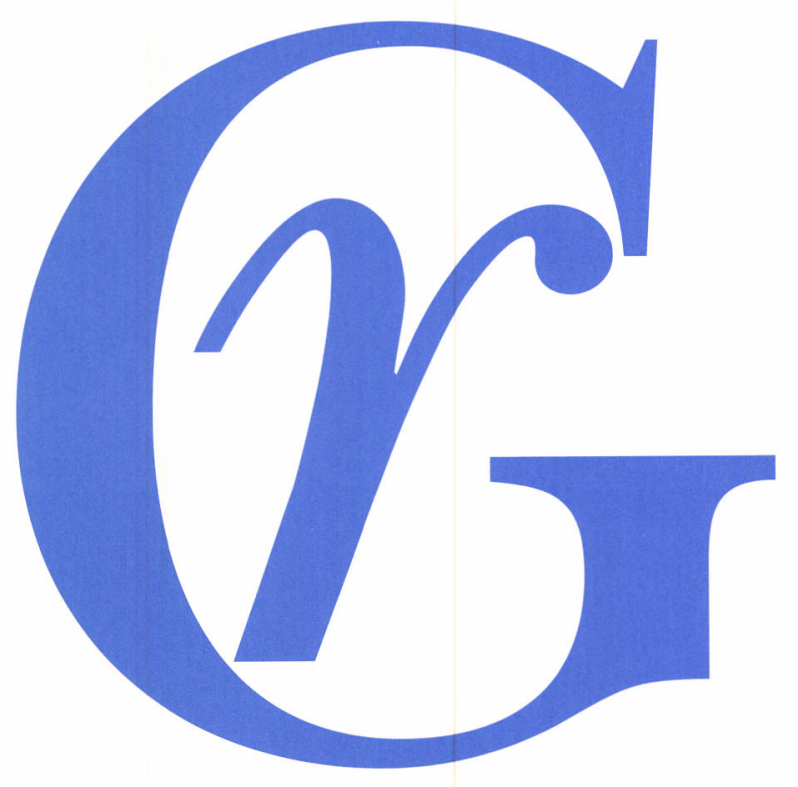


Risk assessment of peak exposure to genotoxic carcinogens 


\section{Risk assessment of peak exposure to genotoxic carcinogens}

H Verhagen

VJ Feron

$\mathrm{PW}$ van Vliet 
Preferred citation:

Health Council of the Netherlands: H Verhagen, VJ Feron, PW van Vliet. Risk assessment of peak exposure to genotoxic carcinogens. The Hague: Health Council of the Netherlands, 1994; publication no. A94/04.

all rights reserved 


\section{Contents}

To the reader 6

Summary 7

Samenvatting 9

$\overline{\text { Introduction } 11}$

$2 \quad$ Previous evaluations 14

3 Relevance of the key question 18

$4 \quad$ Theoretical values of the DRCF 21

4.1 Instantaneous high-dose versus long-term low-dose exposures 21

4.2 Short-term low-dose versus long-term low-dose exposures 23

4.3 Cessation of exposure 24

4.4 Conclusion 25

$5 \quad$ Experiments with genotoxic carcinogens 26

5.1 Single-dose versus multiple-dose exposure regimens - tumour development 26

5.2 Multiple-dose versus extended multiple-dose exposure regimens - tumour development 31

5.3 Experiments with genotoxic carcinogens - parameters other than tumour development 33 


\section{$5.4 \quad$ Conclusions 34}

$6 \quad$ Data on ionising radiation 36

6.1 Low-LET ionising radiation 38

6.2 High-LET ionising radiation 39

6.3 Conclusion 40

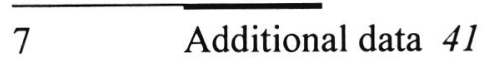

$8 \quad \overline{\text { General discussion } 45}$

$9 \quad \overline{\text { Suggestions for future research } 47}$

References 49

\begin{tabular}{ll}
\hline & Annexes 54 \\
A & Definitions 55 \\
B & Theoretical examples of cancer risk assessment with the DRCF 57 \\
C & List of abbreviations 59
\end{tabular}




\section{To the reader}

The workprogramme 1994 of the Health Council of the Netherlands included the topic 'Influence of the pattern of exposure to hazardous chemicals on the risk associated with that exposure'. I requested H Verhagen, VJ Feron and PW van Vliet to review a part of that topic: the effect on cancer risk of peak exposure to genotoxic carcinogens. The present report summarises the results of this review. Before publication it was assessed by the Council's Standing Committee on Toxicology.

I consider the present report to be a thorough evaluation of the - scarce - data available on peak exposure to genotoxic carcinogens. I conclude from the data that risk assessment of peak exposure to individual genotoxic carcinogens is liable to considerable uncertainty and that more research is needed for well-balanced risk assessment of peak exposure to these agents.

The Hague, 30 December 1994

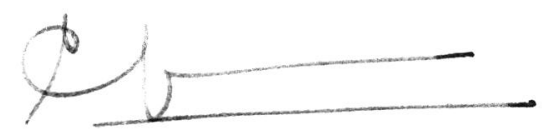

Prof Dr L Ginjaar

President of the Health Council of the Netherlands 


\section{Summary}

Health-based recommended exposure limits, safe doses for lifelong human exposure to chemicals, are estimated from dose-response data obtained in chronic animal experiments or, occasionally, from epidemiological data. These exposure limits are estimated by applying a safety factor to no-observed-adverse-effect levels derived from the data available. This approach is considered inappropriate to estimate limits for human exposure to genotoxic carcinogens. In the Netherlands, for genotoxic carcinogens linear non-threshold extrapolation is applied to the data to estimate the dose corresponding to a certain level of risk for lifelong exposure deemed acceptable by the authorities. Thus, this risk assessment addresses life-time low-dose exposure.

The present report addresses the cancer risk associated with peak exposure, which can occur following accidents or calamities, to a genotoxic carcinogen. For the purpose of this report 'peak exposure' was defined as a single instantaneous exposure (lasting less than 24h) to a high dose of a substance. The key question is: "What is the estimated cancer risk of peak exposure to a genotoxic carcinogen relative to the cancer risk of the same total dose of this carcinogen distributed over an entire lifetime?" For the purpose of answering this question a Dose-Rate Correction Factor (DRCF) was defined as "a factor by which the tumour incidence caused by a specific dose of a chemical carcinogen at low dose rates is multiplied to derive the tumour incidence at high dose rates", and the value of this DRCF was estimated.

The information on the basis of which the key question was answered includes: i) data which are relevant to this question but which did not allow calculation of a DRCF, and statements rather than evaluations of scientific data, ii) theoretical 
calculations of the relative risk of peak exposure, and iii) data on the relative risk of peak exposure to genotoxic chemical carcinogens and ionising radiation. The second and third categories allowed calculation of DRCF values. Some data from the first category were used for the evaluation of these values.

The data reviewed show that peak exposure to a genotoxic chemical may induce cancer. The data also show that the DRCF values for genotoxic carcinogens calculated from experimental studies vary. These values vary from zero to 8.3. Theoretical calculations of DRCF values and derivation of equivalent values from data on ionising radiation also lead to ranges of values. Theoretical calculations result in DRCF values that range from zero to 7.1. Epidemiological and experimental data on the effects of ionising radiation indicate that the Dose-Rate Effectiveness Factor (the radiation equivalent of the DRCF) ranges from 1 to 10 .

An important reason for the variation in DRCF values for genotoxic carcinogens is that the experiments we have based our conclusion on, experiments with genotoxic carcinogens, are limited in number and do not comply exactly with comparison of peak exposure with lifelong exposure to low doses. Furthermore, the experiments differed as to several aspects.

Even though variations in the design of the experiments with the chemicals reviewed may explain the range of DRCF values observed, the additional data on kinetics, metabolism and DNA repair suggest that there is no universal DRCF value, but that the DRCF value is compound-specific. In view of the limitations of the data we regard a DRCF value of 10 appropriate as a 'default' value if no or insufficient data are available to estimate a compound-specific value of the DRCF ('worst-case approach'). 


\section{Samenvatting}

Gezondheidskundige advieswaarden voor chemische stoffen zijn schattingen van het hoogste niveau van blootstelling aan deze stoffen dat nog gezondheidskundig verantwoord is. Als regel hebben zij betrekking op levenslange blootstelling aan lage doses. Zij worden geschat uit dosis-responsgegevens die afkomstig zijn uit dierexperimenten of uit epidemiologisch onderzoek, via toepassing van een veiligheidsfactor op no-observed-adverse-effect levels. Deze (drempelwaarde)benadering wordt niet geschikt geacht voor vaststelling van advieswaarden voor blootstelling van de mens aan genotoxische kankerverwekkende stoffen. In Nederland wordt voor die stoffen een schatting gemaakt van de dosis, die overeenkomt met het risiconiveau dat door de autoriteiten acceptabel wordt geacht bij levenslange blootstelling. Dit gebeurt door toepassing van lineaire, drempelloze extrapolatie van dosis-responsgegevens. Deze schatting richt zich dus op levenslange blootstelling aan lage doses.

Het voorliggende rapport heeft betrekking op de kans op kanker die geassocieerd is met piekblootstelling aan een genotoxische kankerverwekkende stof. Zo'n blootstelling kan bijvoorbeeld optreden na ongelukken of rampen. Onder piekblootstelling wordt in dit rapport verstaan een blootstelling korter dan 24 uur aan een hoge dosis. De centrale vraag is: hoe groot is de verhouding tussen de kans op kanker ten gevolge van piekblootstelling aan een bepaalde dosis van een genotoxische kankerverwekkende stof en de kans op kanker bij spreiding van die dosis over het hele leven? Deze ratio wordt de Dose-Rate Correction Factor (DRCF) genoemd.

De gegevens op basis waarvan de bovengenoemde vraag beantwoord is, zijn: gegevens die relevant zijn voor beantwoording van de vraag, maar die geen berekening 
van een DRCF mogelijk maken, en opinies hierover; theoretische berekening van het relatieve risico van piekblootstelling; gegevens over het relatieve risico van piekblootstelling aan genotoxische kankerverwekkende stoffen en ioniserende straling. Gegevens van de tweede en derde categorie maken berekening van DRCF-waarden mogelijk. Enkele gegevens uit de eerste categorie zijn gebruikt voor de evaluatie van deze DRCF-waarden.

De beschikbare gegevens leiden tot de conclusie dat piekblootstelling aan een genotoxische kankerverwekkende stof kanker tot gevolg kan hebben. Berekeningen op basis van gegevens uit dierexperimenten met genotoxische kankerverwekkende stoffen tonen aan dat de waarden van de DRCF voor genotoxische kankerverwekkende stoffen variëren van 0 tot 8,3 . Theoretische berekening van de $\mathrm{DRCF}$ en berekening van een overeenkomstige grootheid voor ioniserende straling geven ook waarden die uiteenlopen. Theoretische berekening van het relatieve risico van piekblootstelling aan genotoxische kankerverwekkende stoffen leidt tot DRCF-waarden die variëren van 0 tot 7,1. Experimentele en epidemiologische gegevens over blootstelling aan ioniserende straling geven waarden van de Dose-Rate Effectiveness Factor (het equivalent van de DRCF voor straling) die variëren van 1 tot 10 .

Een belangrijke reden voor de gevonden spreiding in DRCF-waarden voor genotoxische kankerverwekkende stoffen is, dat de experimentele gegevens waarop de DRCF-waarden gebaseerd zijn, afkomstig zijn van een klein aantal experimenten die niet precies betrekking hadden op een vergelijking van piekblootstelling en levenslange blootstelling aan lage doses en die bovendien verschilden wat betreft de gebruikte stoffen en de proefopzet.

Hoewel verschillen in de proefopzet de uiteenlopende waarden van de DRCF kunnen verklaren, suggereren de aanvullende gegevens over kinetiek, metabolisme en DNA-herstel dat er geen universele DRCF bestaat, maar dat de waarde van de DRCF specifiek is voor een stof. Bij het ontbreken van stof-specifieke gegevens voor berekening van de DRCF lijkt 10 een geschikte maximale waarde voor de DRCF te zijn ('worst-case' benadering). 


\section{Introduction}

Humans are exposed to small amounts of various chemicals for periods of time that may vary from a single exposure or a few exposures to more or less continuous, lifelong exposure. However, in the case of accidents humans may be exposed to large amounts of chemicals for relatively short periods of time. The magnitude of accidents may range from small-scale accidents involving only a few people, such as a gasleak or a broken bottle, to large-scale chemical disasters like those in Seveso (Italy, 1976, TCDD), Bhopal (India, 1984, methylisocyanate), and Chernobyl (former Soviet Union, 1986, release of radioactive material) exposing hundreds, thousands or even greater numbers of people (Ber89). The toxicity of the compound released and the dose to which people are exposed are the main determinants of the adverse effects.

For many toxic compounds a no-observed-adverse-effect level (NOAEL) exists, at and below which no adverse effects are expected to occur. This applies when the toxic effect is a non-stochastic one. In this case deleterious effects may arise when the dose* to which humans are exposed exceeds the NOAEL. At high doses** a level may be reached at which an exposed human being dies (in case of e.g. release of gases such as hydrogen cyanide or phosgene). At doses between the NOAEL and the lethal dose humans may experience non-lethal adverse effects, either reversible ones, e.g. burns from etching substances like sodium hydroxide, or irreversible ones, e.g. pulmonary damage from methylisocyanate (Fer91). 
However, not all toxic compounds have non-stochastic adverse effects: some carcinogens contribute to the carcinogenic process in a stochastic way. This implies that, for risk assessment, carcinogens can be subdivided according to mechanism of action (GR78, HCN94). This subdivision is relevant to assessment of the risk of exposure to carcinogens under any exposure pattern. Carcinogens acting through a stochastic mode of action, termed genotoxic carcinogens, are capable of inducing irreversible changes in DNA with a self-replicating effect. This group includes initiators and complete carcinogens (GR78). Irreversible action at the molecular level implies that there is no threshold dose for the carcinogenic effect. Carcinogens acting by a non-stochastic mechanism, termed non-genotoxic carcinogens, have a mode of action that is regarded as reversible up to a certain dose (or time) level. This implies the existence of a threshold dose, the NOAEL, at and below which no carcinogenic potential exists. Examples of the latter group are promoters and other substances acting as co-carcinogens (GR78).

In 1978 a committee of the Health Council of the Netherlands proposed an approach to the quantitative assessment of the risk of exposure to carcinogenic substances on the basis of the above-mentioned subdivision (GR78). The committee adopted the one-hit model of cancer induction and proposed, in the case of genotoxic carcinogens, the application of linear extrapolation to the dose-response curve to assess the exposure level associated with a certain, politically accepted excess cancer incidence. In the case of non-genotoxic carcinogens, the committee considered appropriate the threshold approach to estimate safe doses for lifelong exposure from the dose-response curve. Thus, the decision as to whether a stochastic process is involved was considered crucial to carcinogenic risk assessment. Recently, the former and present Committees on the Evaluation of the Carcinogenicity of Chemical Substances of the Council reassessed this approach (GR88, HCN94); they concluded that it is still the most appropriate one.

As exposure to many carcinogens in the environment is lifelong and involves low doses, risk assessment of exposure to these compounds has hitherto mainly focused on the risk associated with this kind of exposure. The consequences, in terms of cancer risk to humans, of accidental exposure to high doses of genotoxic carcinogens ('peak exposure' to genotoxic carcinogens) are the subject of the present report. For the purpose of this report a peak exposure to a substance was defined as 'a single instantaneous exposure' (lasting less than $24 \mathrm{~h}$ ) to a 'relatively high' dose of a substance as compared to a 'relatively long' exposure to a 'relatively low' dose of a substance. The key question to be resolved is:

What is the estimated cancer risk of peak exposure to a genotoxic carcinogen relative to the cancer risk of exposure to the same total dose of this carcinogen distributed over an entire lifetime? 
Thus, this question addresses the comparison of risks of peak and lifelong exposure to a genotoxic carcinogen at equal doses*.

The relative risk of peak exposure to genotoxic carcinogens is expressed as DoseRate Correction Factor (DRCF). The DRCF is defined as 'a factor by which the tumour incidence caused by a specific dose of a chemical carcinogen at low dose rates is multiplied to derive the tumour incidence at high dose rates'. In this report the available data will be evaluated in order to establish a DRCF for peak exposure to genotoxic carcinogens. The DRCF is greater than unity if a peak exposure, as compared to lifelong exposure, increases the tumour incidence, lower than unity if a peak exposure decreases the tumour incidence, and unity if it has no effect on tumour incidence.

To address the key question, relevant papers were reviewed. The database of the 'Deutsches Institut für Medizinische Dokumentation und Information' in Cologne, Germany, was therefore consulted, using the keywords: accident(s), calamity, disaster, carcinogen(s), genotoxic(ity), single dose, high dose, hazard, peak exposure. In addition, information available from personal contacts of the authors was used. However, most of the relevant papers were found among the references of papers in which the key question was (thought to be) referred to. The information obtained was divided into three categories: i) data relevant to this key question but which do not allow calculation of a DRCF, and statements rather than evaluations of scientific data, ii) theoretical calculations of the relative risk of peak exposure, iii) experimental data on the relative risk of peak exposure. The latter category includes data on genotoxic chemical carcinogens as well as ionising radiation, a physical carcinogen acting by a genotoxic mechanism.

The outline of the report is as follows:

- First, data relevant to, and previous opinions on the subject of this report are discussed.

- Second, it is shown that it is possible to develop cancer after a single exposure to a genotoxic carcinogen.

- Third, DRCF values calculated theoretically, or obtained from animal experiments with genotoxic carcinogens, and animal experiments with ionising radiation and from accidental human exposure to ionising radiation will be reviewed.

- Fourth, a DRCF value will be estimated for application to compounds for which data on peak exposure are lacking.

- Fifth, a formula will be provided to estimate the absolute cancer risk associated with peak exposure to a genotoxic carcinogen.

- Finally, suggestions for future research will be given. 


\section{Previous evaluations}

Few others have addressed the key question of the present report. Those who have done so have provided statements on the relative risk of tumour development associated with peak exposure to carcinogens (cf. Table 1), or have presented data which are relevant to the subject of the present report but do not allow derivation of DRCF values.

Several opinions about the risk associated with exposure to a relatively high dose of carcinogen have been published.

Turusov (Tur84: abstract only) suggested that dose fractionation enhances the effectiveness of polycyclic aromatic hydrocarbons (PAHs) and probably decreases the effectiveness of directly acting carcinogens.

The US-Environmental Protection Agency (EPA86) assumes that the DRCF of carcinogens equals unity:

Unless there is evidence to the contrary in a particular case, the cumulative dose received over a lifetime, expressed as an average daily exposure protracted over a lifetime, is recommended as an appropriate measure of exposure to a carcinogen. That is, the assumption is made that a high dose of a carcinogen received over a short period of time is equivalent to a corresponding low dose spread over a lifetime.

In the same paper the US-EPA also recognises that: 
Table 1 Statements on the relative risk of peak exposure (from reviews only).

(range of $n: 1.1-6.5$ ). A single high exposure may induce cancer: a higher dose is needed but the time until tumour development is shorter

Fractionation of dose enhances the effectiveness of PAHs and probably decreases the effectiveness of directly acting carcinogens; tumours in different tissues may respond in a different way

A high dose received over a short period is equivalent to a corresponding low dose spread over a lifetime (unless there is evidence to the contrary) Mutagenicity, carcinogenicity, teratogenicity may arise from a single exposure; generally not possible to Ill89 estimate risk of single exposure as no data are available

- Probability of tumour development after short accidental exposure "extremely low" Cru84))

a instantaneous dose

b virtually safe dose

Positive studies at levels above the Maximum Tolerated Dose (MTD)* should be carefully reviewed to ensure that the responses are not due to factors which do not operate at exposure levels below the MTD. Evidence indicating that high exposures alter tumour responses by indirect mechanisms that may be unrelated to effects at lower exposures should be dealt with on an individual basis.

Illing (Ill89) recognises the possibility of tumour development following a single exposure to a carcinogen but does not consider it possible to estimate the associated risk:

... Other effects, including mutagenicity, carcinogenicity and teratogenicity, may also arise as a result of a single exposure. However, for most Major Hazard substances, single exposure dose-effect data are not available for these effects, and it is not possible to extrapolate satisfactorily to single exposures to man....

'High dose used in chronic toxicity testing that is expected on the basis of an adequate subchronic study to produce limited toxicity when administered for the duration of the test period. It should not induce (a) overt toxicity, for example appreciable death of cells or organ dysfunction, or (b) toxic manifestations that are predicted materially to reduce the life span of the animals except as the result of neoplastic development or (c) $10 \%$ or greater retardation of body weight gain as compared with control animals. In some studies, toxicity that could interfere with a carcinogenic effect is specifically excluded from consideration' (IUPAC93). 
ECETOC (ECE91) also recognises the probability of tumour development following a short accidental exposure to a carcinogen but considers it extremely low:

... The Task Force recognised the importance of cancer as an endpoint but gave weight to the evidence showing that the probability of it occurring as a result of a single, short (accidental) exposure is extremely low. The risk of the population would thus be small compared with that arising from the acutely hazardous effects of chemicals. ...... Emergency Exposure Indices for carcinogens should be set on the basis of acute effects and it must be recognised that their role is confined to the prediction of the occurrence of acute effects.....

Several attempts were made to calculate the risk associated with peak exposure to carcinogens. The Committee on Toxicology of the US National Research Council calculated a one-day instantaneous dose (ID) by multiplying by 25,600 (number of days in an average lifetime) and $2.8^{-1}$ the virtually safe dose (VSD), the daily dose associated with an accepted lifetime risk of one in a million in the USA:

because of uncertainties about which of several stages in the carcinogenic process a material may operate in, and because of the likely low age of military persons, it can be shown from data of Crump and Howe (Cru84) that the maximal additional risk that these considerations contribute is a factor of 2.8. As a conservative approach, the acceptable one-day VSD is divided by 2.8 (COT86).

Thus, according to the Committee on Toxicology, the one-day ID is

$$
I D_{\text {one-day }}=25,600 \times 2.8^{-1} \times V S D
$$

The factor of 2.8 has to be considered as a DRCF. Unfortunately, it was not stated explicitly how this factor was derived from the data of Crump and Howe (Cru84).

Alexeeff and co-workers (Ale89) applied this DRCF to calculate the ID associated with a peak exposure of $30 \mathrm{~min}$ to a variety of carcinogens:

$$
I D_{30-\min }=25,600 \times 48 \times 2.8^{-1} \times V S D
$$

Druckrey and co-workers have performed a number of studies on the relation between carcinogenic dose and tumour induction time (reviewed in Dru67). Although they did not derive any DRCF values themselves, the results of their experiments are relevant to the interpretation of the DRCF values reviewed or calculated in the next chapters. They showed that at continuous exposure with all genotoxic substances tested (4-dimethylaminobenzene, 4-dimethylaminostilbene, $\mathrm{N}$-nitrosodiethylamine and other 
nitrosoalkylethylamines) and without regard to the target organ clear dose-response and dose-time relationships exist, which are explained by the general formula:

$$
d \times t^{n}=\text { constant }
$$

where $d$ is the daily dose, $t$ the tumour induction time, $n$ a numerical value depending on the substance in question.

The numerical value of $n$ differs considerably with different carcinogens, ranging from 1.1 to 6.5 and thus can be considered as an indicator of the carcinogenic potency of a compound. Druckrey (Dru67) showed that experimental data on PAHs, established by others, also fitted the above formula. The author concluded that this formula is consistent with results of experiments showing that a single exposure can cause tumours to develop (Mag59, Dru64). These experiments resulted in tumours even if the carcinogen was degraded metabolically or excreted within a few hours.

Recently, the validity of Druckrey's formula was confirmed in a series of chronic studies using thousands of rodents exposed to N-nitrosodiethylamine or N-

nitrosodimethylamine, $n$ ranging from 1 to 2.3 (Swe91, Pet91a, Pet91b, Gra91a). The impact of the formula is that 1) a higher dose is needed to induce a certain cumulative tumour incidence if short-term exposure to a high dose rate takes place instead of long-term exposure to a low dose rate; 2) the time needed for development of a certain cumulative tumour incidence is shorter following exposure to a high dose rate as compared to exposure to a low dose rate at equal doses.

In conclusion, opinions vary as to the effectiveness of high dose rates as compared to low dose rates. A shortcoming of the statements presented in this chapter is that no distinction was made between genotoxic and non-genotoxic compounds. The results presented by Druckrey and co-workers (Dru67) were obtained with genotoxic carcinogens only. They demonstrate that the tumour incidence depends critically on the time point of recording of this incidence. 


\section{Relevance of the key question}

A prerequisite for the establishment of a DRCF of peak exposure to a genotoxic carcinogen is a positive answer to the following question: can peak exposure to a genotoxic carcinogen lead to tumour development? Were the answer 'no' there would be no tumour development, and the DRCF would be zero; were it 'yes', a DRCF greater than zero can be established. In the latter case the DRCF is greater than unity if a peak exposure, as compared to lifelong exposure, increases the tumour incidence, lower than unity if a peak exposure decreases the tumour incidence, and unity if it has no effect on tumour incidence.

The use of a single administration or a few administrations of a carcinogen has been common practice in many tumour models involving laboratory animals. Table 2 lists some experiments in which the tumour incidence was increased by a single application of a genotoxic carcinogen. Compounds, a single administration of which leads to tumour development, may be both directly acting genotoxic carcinogens (e.g. methylnitrosurea (MNU)) and indirectly acting ones, i.e. compounds needing bioactivation to react with DNA (e.g. vinyl chloride monomer, several nitrosamines, several PAHs). Thus, there is ample evidence from animal studies that a single exposure to a genotoxic carcinogen may increase the cancer incidence.

There are scant data suggesting that a peak or short-term exposure to a genotoxic compound can give rise to tumours in humans. Markovitz and Crosby (Mar84) reported that two out of nine firemen who were exposed to 1,3-dichloropropene (1,3-DCP) after a spill, developed non-Hodgkin lymphoma almost simultaneously 6-7 years after exposure. They also reported on the case of a man who was exposed to 
Table 2 Examples of tumour development after single administration of chemicals to laboratory animals.

\begin{tabular}{|c|c|c|c|c|c|}
\hline$\overline{\text { agent }^{\mathrm{a}}}$ & b.act ${ }^{b}$ & species/route & dose & effect & ref \\
\hline \multicolumn{6}{|c|}{$N$-nitroso compounds } \\
\hline MNU & no & $\begin{array}{l}\text { rat } \\
\text { i.v. }\end{array}$ & $70-100 \mathrm{mg} / \mathrm{kg}$ body weight & tumours in multiple organs & Dru64, Dru67 \\
\hline $\begin{array}{l}\text { Various } \\
\text { nitrosamines }^{c}\end{array}$ & yes & $\begin{array}{l}\text { rat } \\
\text { i.v., inh., p.o. }\end{array}$ & $37-370 \mathrm{mg} / \mathrm{kg}$ body weight & tumours in multiple organs & Dru64, Dru67 \\
\hline DBN & yes & hamster & $\begin{array}{l}200-800 \mathrm{mg} / \mathrm{kg} \text { body weight i.p. } \\
150-1200 \mathrm{mg} / \mathrm{kg} \text { body weight s.c. } \\
400-1600 \mathrm{mg} / \mathrm{kg} \text { body weight p.o. }\end{array}$ & $\begin{array}{l}\text { mainly papillomas of the } \\
\text { trachea }\end{array}$ & Alt73 \\
\hline DENA & yes & $\begin{array}{l}\text { rat } \\
\text { p.o. }\end{array}$ & $200 \mathrm{mg} / \mathrm{kg}$ body weight & kidney tumours & $\operatorname{Sch} 79$ \\
\hline DENA & yes & $\begin{array}{l}\text { hamster } \\
\text { s.c. }\end{array}$ & $0.75-4.0 \mathrm{mg} / \mathrm{kg}$ body weight & tracheal papillary tumours & Moh70 \\
\hline NNK & yes & $\begin{array}{l}\text { hamster } \\
\text { s.c. }\end{array}$ & $9,31,93 \mathrm{mg} / \mathrm{kg}$ body weight & $\begin{array}{l}\text { tumours of lung, nasal } \\
\text { mucosa, trachea }\end{array}$ & Hec83 \\
\hline NNK & yes & $\begin{array}{l}\text { mouse } \\
\text { i.p. }\end{array}$ & $2.5,5,10 \mu \mathrm{mol}$ & lung tumours & Hec89 \\
\hline \multicolumn{6}{|c|}{ Polycyclic aromatic hydrocarbons } \\
\hline Various PAHs ${ }^{d}$ & yes & $\begin{array}{l}\text { rat } \\
\text { p.o. }\end{array}$ & $20-100 \mathrm{mg} / \mathrm{rat}$ & mammary tumours & Hug62 \\
\hline DMBA & yes & $\begin{array}{l}\text { mouse } \\
\text { skin }\end{array}$ & $51.2 \mu \mathrm{g}$ & $\begin{array}{l}\text { papillomas and carcinomas } \\
\text { of skin }\end{array}$ & Ive86, Ive88 \\
\hline $\mathrm{BP}\left(\& \mathrm{Fe}_{2} \mathrm{O}_{3}\right)$ & yes & $\begin{array}{l}\text { hamster } \\
\text { i.t.i. }^{\text {b }}\end{array}$ & $\begin{array}{l}37.5 \mathrm{mg} \mathrm{BP}\left(\& 12.5 \mathrm{mg} \mathrm{Fe}_{2} \mathrm{O}_{3}\right) \\
5 \mathrm{mg} \mathrm{BP}\left(\& 45 \mathrm{mg} \mathrm{Fe} \mathrm{O}_{3}\right)\end{array}$ & $\begin{array}{l}\text { carcinomas and benign } \\
\text { tumours in lung } \\
\text { benign tumours in lung }\end{array}$ & Saf72 \\
\hline DMBA & yes & rat & $\begin{array}{l}30 \mathrm{mg} / \mathrm{kg} \text { body weight i.v. } \\
1 \mathrm{mg} / \mathrm{rat} \text { locally }\end{array}$ & $\begin{array}{l}\text { mammary tumours } \\
\text { mammary tumours }\end{array}$ & $\operatorname{Sin} 80$ \\
\hline DBA, 20-MC, B & yes & $\begin{array}{l}\text { mouse } \\
\text { s.c. }\end{array}$ & range of doses & $\begin{array}{l}\text { spindle cell carcinomas at } \\
\text { injection site }\end{array}$ & Bry 43 \\
\hline 3-MC & yes & $\begin{array}{l}\text { mouse } \\
\text { skin }\end{array}$ & $63-1000 \mu \mathrm{g}$ & $\begin{array}{l}\text { papillomas and carcinomas } \\
\text { of the skin }\end{array}$ & Ive64 \\
\hline
\end{tabular}


Table 2 continued

\begin{tabular}{llllll}
\hline agent & b.act & species/route & dose & effect & ref \\
\hline $\begin{array}{llll}\text { Other } \\
\text { VCM }\end{array}$ & yes & $\begin{array}{l}\text { mouse } \\
\text { inhal. }\end{array}$ & 5,000 or $50,000 \mathrm{ppm}$ for $1 \mathrm{~h}$ & $\begin{array}{l}\text { pulmonary adenomas and } \\
\text { carcinomas }\end{array}$ & Heh81 \\
URE & yes & $\begin{array}{l}\text { mouse } \\
\text { i.p. }\end{array}$ & $1 \mathrm{mg} / \mathrm{kg}$ body weight & pulmonary tumours & Shi55 \\
\hline
\end{tabular}

a abreviations of compounds: see list of abbreviations

b b.act: need for bioactivation (no = direct carcinogen; yes = indirect carcinogen); i.t.i.: intratracheal instillation

c compound (dose; route): DMNA (37 mg/kg body weight; inh.); DENA (280 mg/kg body weight; i.v.; p.o.); methylvinylnitrosamine (44 mg/kg body weight; inh.): ethylbutylnitrosamine ( $370 \mathrm{mg} / \mathrm{kg}$ body weight; p.o.)

d compound (dose; \% tumour incidence): 12-methylbenz[a]antracene (100 mg; 17\%); 7-methylbenz[a]anthracence (100 mg; $31 \%)$; DMBA (20 mg; 100\%); BP (100mg; 89\%; 2-aminophenanthrene (70 mg; 100\%); 2,4,7-trinitro-9-fluorenone (100 mg; $35 \%)$

1,3-DCP from a leaking hose for about 30 days and who died of acute myelomonocytic leukaemia about one year thereafter.

In addition, the potential of a short-term exposure to ionising radiation to induce cancer is well-known (cf. chapter 6).

In conclusion, the question of whether a single exposure to a genotoxic carcinogen may give rise to tumour formation can be answered by 'yes'. 
Chapter 4

\section{Theoretical values of the DRCF}

Several studies have been published in which the effects on tumour incidence of aberrant, i.e. other than lifetime low-dose exposure patterns to carcinogens were calculated theoretically (Table 3). These studies can be divided into three categories: 1) studies on the effects of instantaneous high-dose exposures versus long-term low-dose exposures, 2) studies on the effects of short-term low-dose exposures versus long-term lowdose exposures, 3 ) studies on the effects of cessation of exposure. The comparison of different patterns of exposure to equal total doses of genotoxic carcinogens was the object of the studies from categories 1 and 2 . Strictly speaking, the results of studies from categories 2 and 3 do not apply to the key question of this report because, in these studies, there was either no question of peak exposure (category 2) or no question of comparison of different patterns at equal total doses (category 3 ). However, all categories will be discussed below as all contribute to an understanding of the effects of peak exposure to a genotoxic carcinogen.

\subsection{Instantaneous high-dose versus long-term low-dose exposures}

Two papers treat theoretically the relative risk of tumour development after instantaneous exposure to genotoxic carcinogens, one using the Armitage-Doll multi-stage (AD$\mathrm{ms}$ ) model (Cru84) and one based upon the Moolgavkar-Venzon-Knudson 2-stage lifedeath (MVK-2s) model (Che88) (Table 3). They both address the dependence of this relative risk on the timing of the peak exposure to, and the stage of carcinogenesis 
Table 3 DRCFs for peak exposure calculated theoretically ${ }^{\mathrm{a}}$.

\begin{tabular}{llll}
\hline model & premisses for peak exposure & DRCF & ref \\
\hline AD-ms & early in life $(0 \mathrm{y}), 1$ st stage affected & 3.0 to $6.0^{\mathrm{b}}$ & Cru84 \\
& early in life $(0 \mathrm{y})$, penultimate stage affected & zero & \\
& late in life $(60 \mathrm{y}), 1$ st stage affected & 0.0004 to $0.06^{\mathrm{b}}$ & \\
& late in life $(60 \mathrm{y})$, penultimate stage affected & 0.7 to $2.3^{\mathrm{b}}$ & \\
& & & Che88 \\
MVK-2s & early in life $(0 \mathrm{y})$, initiator & 2.3 to $7.1^{\mathrm{c}}$ & \\
& early in life $(0 \mathrm{y})$, completer & zero & \\
& late in life $(60 \mathrm{y})$, initiator & 0.01 to $0.2^{\mathrm{c}}$ & \\
& late in life $(60 \mathrm{y})$, completer & 1.8 to $2.6^{\mathrm{c}}$ & \\
\hline
\end{tabular}

a An instantaneous high exposure is compared with protracted exposure (protraction over a lifetime of 70 years)

b Range depends on assumed number of stages in the carcinogenic process

c Range depends on extent of cell proliferation assumed

affected by the carcinogen, assuming that the stages of the carcinogenic process are sequential.

Crump and Howe (Cru84) developed mathematical expressions for the AD-ms model for estimation of risks with various exposure patterns. The assumption underlying their calculations is that neoplastic transformation requires three to six changes in the cellular genome. The risk at age 70 from an instantaneous exposure was compared to the risk associated with exposure to the same total dose distributed uniformly over 70 years. The results of the calculations indicate that the risk depends upon 1) the number of stages in the AD-ms model, 2) the stage affected by the carcinogen, and 3) the age at which the instantaneous exposure takes place (Table 3 ). If the first stage of carcinogenesis is affected, instantaneous exposure at birth gives a risk 3- to 6-fold higher than exposure continued throughout life. The variation depends on the number of stages assumed: higher numbers of stages are associated with higher values. If the first stage is affected, instantaneous exposure occurring later in life is associated with a lower risk. If, on the other hand, the penultimate stage of carcinogenesis is affected, instantaneous exposure at birth gives zero risk at any of 3 to 6 stages. At the age of 60 instantaneous exposure to a carcinogen affecting the penultimate stage gives a lower or higher risk, depending on the number of stages assumed: higher numbers of stages are associated with higher risks. If the penultimate stage of carcinogenesis is affected the maximum relative risk is 2.3 at 6 stages. In conclusion, if the first stage of carcinogenesis is affected by a compound, early peak exposures to this compound are more dangerous than later ones. If the penultimate stage is affected, however, late exposures 
present a higher risk than early ones. In the former and latter situations the upper DRCFs are 6.0 and 2.3 , respectively.

Chen and colleagues (Che88) derived age-specific cumulative hazard functions for evaluation of the risk attached to various patterns of exposure to carcinogens on the basis of the MVK-2s model. An assumption underlying this model is that two sequential changes in the cellular genome are required for malignant transformation: the first would be brought about by an 'initiator', the second by a 'completer'. Cell division is an additional essential feature of the model. The relative risk at age 70 was calculated for instantaneous exposure at 0,20 or 60 years of age, assuming background cell proliferation of $1 \%, 5 \%$ or $10 \%$. The results indicate that the risk depends upon 1) the stage affected by the carcinogen, 2) the age at which exposure takes place, 3) the rate of cell proliferation assumed. Instantaneous exposure to an initiator at birth would give rise to a DRCF varying from 2.3 to 7.1 , the variation depending on the rate of cell proliferation assumed. Instantaneous exposure to an initiator at 60 years of age, however, would give rise to a DRCF varying from 0.01 to 0.2 . In contrast, instantaneous exposure to a completer at birth is associated with a DRCF of zero at any of the assumed rates of cell proliferation, and instantaneous exposure at 60 years of age with a DRCF varying from 1.8 to 2.6 . Thus, instantaneous exposure to an initiator early in life is more dangerous than similar exposure late in life. The upper DRCF value calculated for an initiator is 7.1. Instantaneous exposure to a completer late in life is associated with a higher risk than early exposure. The upper DRCF value calculated for a completer is 2.6 .

The conclusions drawn from the two studies mentioned above are consistent. Both studies show the dependence of the theoretical risk attached to peak exposure to a carcinogen on the age at which exposure takes place and the stage of carcinogenesis affected by the carcinogen in question. Both studies showed that, theoretically, the risk attached to peak exposure is highest if this exposure occurs early in life and involves a compound affecting an early stage of carcinogenesis. Even though the assumptions underlying the models used in both studies differ considerably, the upper values of the DRCF calculated for this worst situation, i.e. 6.0 (Cru84) and 7.1 (Che88), are in close agreement.

\subsection{Short-term low-dose versus long-term low-dose exposures}

Two groups compared the theoretical risks of short-term and long-term exposure, both resulting in equal cumulative doses (Kod87, Mur88). A limitation of the results presented is that the exposures compared both refer to 'low' dose rates. Kodell et al. (Kod87) compared the risk associated with short-term exposure to that associated with exposure protracted over a lifetime, based on the AD-ms model (Table 4). For this 
Table 4 DRCFs for short-term exposure calculated theoretically

\begin{tabular}{|c|c|c|c|c|}
\hline Model $^{\mathrm{a}}$ & Short exposure & Long exposure & $\mathrm{DRCF}$ & Ref \\
\hline $\mathrm{AD}-\mathrm{ms}$ & 1 year starting at birth & lifetime $^{b}$ & $\max . \mathrm{k} / \mathrm{r}^{\mathrm{c}}$ & Kod87 \\
\hline $\mathrm{AD}-\mathrm{ms}$ & d & lifetime & $\max . \mathrm{k}$ & Mur88 \\
\hline MVK-2s & d & lifetime & $\begin{array}{l}\max . \infty \text { at extremely high cell prolifera- } \\
\text { tion, otherwise max. } 1.5\end{array}$ & Mur88 \\
\hline
\end{tabular}

a AD-ms: Armitage-Doll multistage model of cancer; MVK-2s: Moolgavkar-Venzon-Knudson 2-stage life-death model of cancer

b $70 \mathrm{y}$

c $\quad \mathrm{k}$ : total number of stages; $\mathrm{r}$ : number of carcinogen-dependent stages; $1<\mathrm{r}<\mathrm{k}$

d time point and duration vary

purpose the authors assumed a varying number of stages affected by the carcinogen in a carcinogenic process consisting of two to six stages. Short-term exposure had a minimum duration of one year; the human lifespan was assumed to be 70 years. The results of the calculations show that short-term exposure enhances the risk by a factor which is lower than the number of stages in the model divided by the number of carcinogendependent stages. In the case of a 1-yr exposure the risk is highest if 6 stages are involved, only the first stage is carcinogen-dependent, and exposure starts at birth. In this case the risk is 5.8 times that of lifelong exposure.

Similar calculations were performed by Murdoch and Krewski (Mur88) with both the AD-ms model and the MVK-2s model. The conclusions obtained using the AD-ms model confirm those of Kodell et al. (Kod87). According to the MVK-2s model, the relative risk associated with short-term exposure depends on the postulated contribution of promotion. If a constant level of cell proliferation is assumed, the relative risk increases with the level of proliferation and shows no upper limit. If cell proliferation is dose-dependent the upper limit is 1.5 .

\subsection{Cessation of exposure}

Day and Brown (Day80, Bro83) predicted the theoretical effect of cessation of exposure to genotoxic carcinogens using the AD-ms model of carcinogenesis. They compared a theoretical tumour incidence after cessation of exposure and continuation of treatment. Additionally, they tested their predictions against experimental and epidemiological data for a few carcinogens. They showed that multi-stage models with more than two stages needed for tumour development predict two patterns of changing 
risk following cessation of exposure to a genotoxic carcinogen; these patterns depend on the stage of the process affected by the carcinogen. The authors predicted that the drop in risk following removal of a carcinogen affecting an early stage is slow, whereas removal of a carcinogen affecting a late stage leads to a more rapid reduction in risk. They also reviewed published experimental and epidemiological data in the light of their predictions. The data Day and Brown considered demonstrated that the two types of risk reduction predicted do occur, although it seems that more than one stage can be affected by a carcinogen. DRCF values could not be calculated because there was no question of equal total exposures with the exposure patterns compared. However, they showed that discontinued exposure to a genotoxic carcinogen is sufficient to cause tumours. They also showed that the risk associated with this exposure pattern can be estimated.

\subsection{Conclusion}

Whatever model of carcinogenesis is preferred, theoretically, peak exposure to an agent affecting an early stage of carcinogenesis has the greatest effect on the risk of tumour development when exposure takes place early in life. Alternatively, peak exposure to an agent affecting a late stage of carcinogenesis has the greatest effect when the exposure takes place late in life. The former situation is associated with a higher risk than the latter one. The calculations by Crump and Howe (Cru84) and Chen et al. (Che88) indicate that, at worst, under the assumptions presented, the DRCF of peak exposure is 7. The effects of short-term low-dose exposures and cessation of exposure other than those of short-term low-dose exposure at extremely high rates of cell proliferation, are qualitatively consistent with these findings. 


\section{Experiments with genotoxic carcinogens}

Studies comparing the effects on tumour development of the extremes of exposure, i.e. of single exposure to a high dose and lifelong exposure to a low dose, have not been performed. There are only studies comparing the effects of short exposure to high doses and longer exposures to low doses. These can be subdivided into studies in which the same amount of substance was administered as a single dose (representing peak exposure) or as multiple doses and those in which the same total amount was administered as multiple or extended numbers of doses. Both types of studies are reviewed in this chapter. In addition, two studies comparing the effects of dose-rate differences on parameters other than, but relevant to, tumour incidence are discussed.

\section{$5.1 \quad$ Single-dose versus multiple-dose exposure regimens - tumour development}

In the seven studies in which the tumour incidence following one insult with a genotoxic carcinogen was compared with that following multiple insults, the total dose was spread over a maximum of 2 to 50 fractions (Table 5).

White et al. (Whi70) investigated the occurrence of lung tumours in groups of 27 or 28 mice injected intraperitoneally with urethan (URE) (ethyl carbamate), once at 1 $\mathrm{mg} / \mathrm{g}$ body weight and twice at $0.5 \mathrm{mg} / \mathrm{g}$ body weight six days apart. The authors did not report the tumour incidence, but reported the mean number of tumours per animal at 12-24 weeks after the initial (or only) injection. Therefore, we calculated a DRCF on the basis of this parameter instead of tumour incidence. Using the data from 
Table 5 Experiments on tumour incidence following single or multiple administration of genotoxic carcinogens.

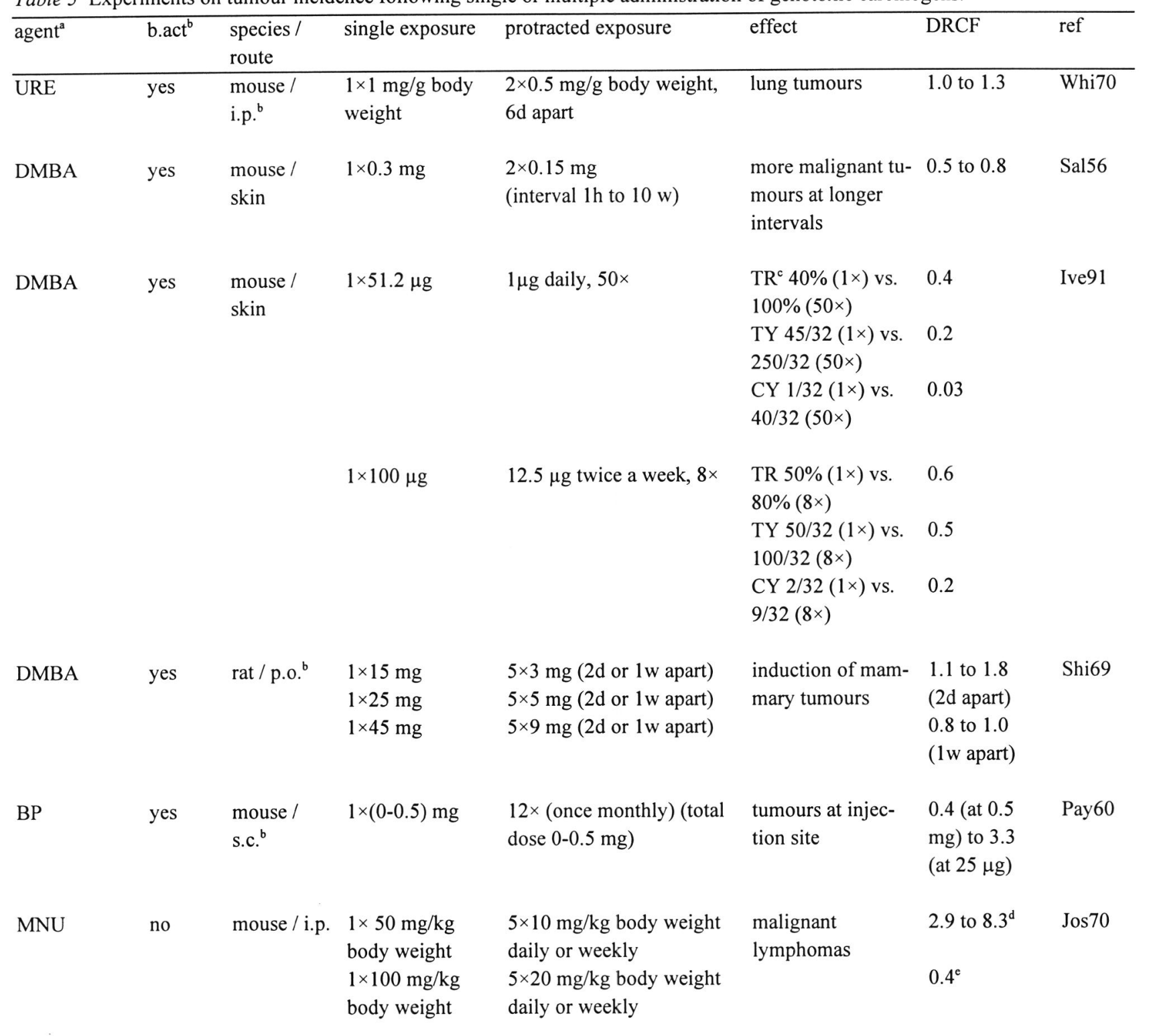

abbreviations of compounds: see list of abbreviations

b b. act: need for bioactivation ( no = direct carcinogen; yes = indirect carcinogen); i.p.: intraperitoneally; p.o.: per os (stomach tube); s.c.: subcutaneously

c TR: tumour rate ; TY: tumour yield ; CY: carcinoma yield

d spreading the dose over 5 weekly treatments caused fewer tumours than did spreading over 5 daily treatments

e $\quad 100 \mathrm{mg} / \mathrm{kg}$ as single dose caused high early lethality (60\% within 2 weeks after treatment) 
Table 5 Continued

\begin{tabular}{|c|c|c|c|c|c|c|c|}
\hline agent & b.act & $\begin{array}{l}\text { species / } \\
\text { route }\end{array}$ & single exposure & protracted exposure & effect & DRCF & ref \\
\hline NHMI & yes & rat / s.c. & $\begin{array}{l}1 \times 133 \mathrm{mg} / \mathrm{kg} \\
\text { body weight }\end{array}$ & $\begin{array}{l}10 \times 13.3 \mathrm{mg} / \mathrm{kg} \text { body } \\
\text { weight in } 10 \mathrm{w} \\
8 \times 16.6 \mathrm{mg} / \mathrm{kg} \text { body } \\
\text { weight in } 4 \mathrm{w}\end{array}$ & $\begin{array}{l}\text { tumours in upper } \\
\text { digestive tract and } \\
\text { in respiratory tract }\end{array}$ & $0^{f}$ & Tay 75 \\
\hline 1,3-butadiene & yes & $\begin{array}{l}\text { mouse / } \\
\text { inhalation }\end{array}$ & $\begin{array}{l}1000,5000 \text { or } \\
10,000 \mathrm{ppm} \\
\text { for } 2 \mathrm{~h}\end{array}$ & not done & no tumours & $0^{\mathrm{f}}$ & Buc93 \\
\hline
\end{tabular}

no tumours in the single exposure group

animals 8.5 weeks of age at the first (or only) injection, a DRCF of 1.3 was obtained. Using the data from younger animals a lower value was obtained.

Salaman and Roe (Sal56) treated groups of ten mice of unreported age topically with a small amount of the PAH 9,10-dimethyl-1,2-benzanthracene (DMBA), using $0.3 \mathrm{mg}$ per animal once or $0.15 \mathrm{mg}$ per animal twice, followed by treatment with a tumour-promoting course of croton oil. The interval between the two applications of DMBA varied from one hour to ten weeks. Weekly application of croton oil was started at thirteen weeks and was stopped after fifteen applications. The parameter investigated by Salaman and Roe and used by us for calculation of a DRCF was the incidence of malignant tumours. Dividing the initiating dose into two halves yielded DRCF values varying from 0.5 to 0.8 , the variation depending on the interval between the two halves.

Iversen (Ive91) analysed the incidence of skin tumours in large groups of hairless mice ( 32 or more mice per group) with various doses of DMBA at various dose rates painted on the skin. The experiments lasted till death or tumours occurred, 60 to 80 weeks. The data that allowed calculation of DRCF values concerned doses of approximately 50 and $100 \mu \mathrm{g}$. Iversen compared the tumourigenic effect of a single dose of $51.2 \mu \mathrm{g}$ and of 50 daily fractions of $1 \mu \mathrm{g}$ DMBA. He also tested less extensive fractionation of the single dose: 6 times $10 \mu \mathrm{g}$ or 20 times $2.6 \mu \mathrm{g}$. He further tested a dose of $100 \mu \mathrm{g}$ and fractions thereof, although in this case the maximum number of fractions tested was only 8 . The results show that dividing a particular dose of DMBA into an increasing number of applications had a greater tumourigenic and carcinogenic effect than increasing the single dose itself. A single dose of $51.2 \mu \mathrm{g}$ gave a tumour rate (incidence) of about 40 per cent, whereas 50 administrations of $1 \mu \mathrm{g}$ gave a tumour rate of almost 100 per cent. The DRCF value we calculated from these data was 0.4 . If a parameter other than tumour incidence e.g., the cumulative number of tumours 
(tumour yield), were used to derive a DRCF, a lower value would result (cf. Table 5). The DRCF values at $100 \mu \mathrm{g}$ DMBA based on tumour rate and yield are 0.6 and 0.5 , respectively.

Shimkin et al. (Shi69) treated groups of 20 or 30 rats orally with doses of 15, 25 or $45 \mathrm{mg}$ of DMBA. The rats were 7 weeks of age when treatment was started; the experiment was stopped at 34 weeks after the first (or only) administration. The effects of single administrations were compared to those of five administrations every other day and five administrations weekly, the parameters investigated being the incidence of mammary tumours and the number of tumours per rat. The highest total dose caused early mortality, as demonstrated by survival rates of 57 and 47 per cent at four weeks in the groups receiving a single administration and administrations two days apart, respectively. The other cumulative doses tested did not have this effect. The DRCF derived from the effect of single exposure on tumour incidence and that of spreading over five administrations every other day ranges from 1.1 to 1.8 , the range depending on the dose tested. Exclusion of the data for the highest dose would only modify the DRCF slightly: it would reduce the upper DRCF from 1.8 to 1.5. The DRCF derived from the effect of single exposure and that of spreading over five administrations weekly is $0.8-1.0$. Exclusion of the data for the highest dose would not modify this range. Thus, the early mortality hardly influenced the value of the DRCF.

Payne and Hueper administered a single dose or twelve monthly fractions of the PAH benzo(a)pyrene (BP) to large groups of mice ( 72 mice per group) by subcutaneous injection and investigated the frequency of tumours at the site of injection (Pay60). The animals were ten weeks old when first injected; the total amount of BP per mouse ranged from 0 to $0.5 \mathrm{mg}$. The incidence of tumours at the site of injection was recorded after three-month intervals until the end of the experiment at 24 months. The design of this study allows an analysis of the influence on the DRCF of the point in time at which the dosing regimens are compared. The DRCF calculated from the tumour incidences observed at the end of the experiment was 3.3 at the lowest dose of BP administered $(25 \mu \mathrm{g})$. The DRCF was unity at the next higher dose and gradually decreased with increasing doses to 0.4 at the highest amount of BP $(0.5 \mathrm{mg})$. Thus, the dose influences the DRCF, lower amounts leading to higher values, at least in the dose range investigated. The DRCF calculated from the tumour incidences observed after 12 months varied from 6.0 at the lowest dose to 0.6 at the highest dose. These DRCF values are higher than the corresponding ones at 24 months. In conclusion, the actual value of the DRCF depends critically on the time point of recording of tumour incidence, a later time point being associated with a lower value. This is in line with the results of Druckrey (Dru67) discussed in chapter 2. As a consequence, the most relevant $\mathrm{DRCF}$ values for the purpose of answering the key question of the present report 
are those calculated from the tumour incidences observed at the end of the experiment. These DRCF values range from 0.4 to 3.3 .

Joshi and Frei (Jos70) investigated the incidence of malignant lymphoma in mice (30 mice per group) treated with the nitrosamine, methylnitrosourea (MNU) at various dose rates. The authors investigated the effects of amounts of 50 or $100 \mathrm{mg} / \mathrm{kg}$ body weight applied intraperitoneally as single doses or distributed over five administrations daily or weekly. The incidence of malignant lymphoma was evaluated 35 weeks after the first (or only) injection. The DRCF values obtained with a dose of $100 \mathrm{mg} / \mathrm{kg}$ were 0.4 for comparison of a single exposure with each of the two regimens of protracted exposure tested. The DRCF values obtained with a dose of $50 \mathrm{mg} / \mathrm{kg}$, not enhancing early mortality, were 2.9 and 8.3 for comparison of peak exposure with protraction over five administrations daily and weekly, respectively. The values obtained with 100 $\mathrm{mg} / \mathrm{kg}$ may have been biased by the high early mortality ( 60 percent), observed in the group receiving the single dose. Considering only the DRCFs obtained with a cumulative dose of $50 \mathrm{mg} / \mathrm{kg}$ of MNU, the DRCF comparing peak exposure with five administrations weekly is the most appropriate factor for our purpose, because it involves the most extensive protraction of exposure. This factor is 8.3.

Taylor and Nettesheim (Tay75) compared the effects on tumour incidence of subcutaneous injection of the nitrosamine nitrosoheptamethyleneimine at various dose rates in rats (6 to 16 rats per group). The effect of a single subcutaneous injection of a dose of $133 \mathrm{mg} / \mathrm{kg}$ body weight was compared to the effect of fractionation into eight or ten injections. In the two groups of rats exposed to protracted dosing, tumours were found in the respiratory and upper digestive tracts; none of the six animals in the group of rats that received a single injection had developed tumours after 90 weeks, when the experiment was terminated. Therefore, the DRCF is zero.

In addition to these seven studies in which tumour incidence following one insult with a genotoxic carcinogen was compared with that following multiple insults, one further study should be mentioned. This is a study in which the tumourigenicity of 1,3-butadiene was investigated by peak exposure of mice (Buc93). Groups of 60 male and 60 female mice were exposed to $0,1000,5000$, or 10,000 ppm of 1,3-butadiene. The exposure conditions and methods were similar to those reported for studies exposing mice to lower concentrations for longer periods, resulting in tumour development. The incidence of tumours was evaluated after two years. The tumour incidence was not increased after peak exposure to the above-mentioned doses of 1,3-butadiene. Thus, the DRCF for 1,3-butadiene is zero. 


\subsection{Multiple-dose versus extended multiple-dose exposure regimens - tu- mour development}

Values of the DRCF for peak exposure could not be calculated from any of the data reported in this section, because single exposure was not included in any of the studies to be discussed. Therefore, we calculated DRCF values by replacing data for the tumour incidence following single exposure by data for tumour incidence following the shortest exposure. In two studies in which the effect of multiple fractions of a dose of a compound was compared with that of an extended number of fractions of that same dose, the numbers of fractions compared were 5 versus 20 (or 10) (McC81) and 10 versus 100 (Heh81) (Table 6). In a third study, exposure patterns were not compared in terms of the number of fractions but in terms of duration of exposure (Lit85). In this latter study the comparison concerned approximately equal doses.

McCormick et al. ( $\mathrm{McC} 81)$ investigated the incidence of urinary bladder cancer in mice (25 mice per group) instilled intragastrically with doses of 15,20 or $30 \mathrm{mg}$ of the nitrosamine, N-butyl-N-(4-hydroxybutyl)nitrosamine (OH-BNN), each distributed over 5,10 or 20 weekly fractions. These authors evaluated tumour incidence at the end of the experiment, six months following the first oral administration of OH-BNN. Administration of $\mathrm{OH}-\mathrm{BNN}$ as 20 weekly fractions was slightly more effective to induce cancer than was administration as five fractions; the 10 -fraction protocol was of intermediate effectiveness. Calculation of the DRCF led to the following values. At a dose of $15 \mathrm{mg} \mathrm{OH}-\mathrm{BNN}$ the DRCF was zero, because tumours did not occur in the group receiving five fractions. At a dose of $20 \mathrm{mg} \mathrm{OH}-\mathrm{BNN}$ the DRCF value for 5 versus 10 fractions was 0.3 , that for 5 versus 20 fractions, 0.1 . At $30 \mathrm{mg}$ these values were 0.2 and 0.1 , respectively.

Hehir et al. (Heh81) exposed mice (ca. 160 per group) to vinyl chloride monomer by inhalation and recorded the incidence of pulmonary tumours. The exposure regimens compared were ten 1 -hr exposures to $500 \mathrm{ppm}$ ( $1 \mathrm{hr} /$ day, 5 days/wk for 2 weeks) vinyl chloride monomer and $1001-\mathrm{hr}$ exposures to $50 \mathrm{ppm}(1 \mathrm{hr} /$ day, 5 days/wk for 20 weeks). The mice were killed 20 months after exposure. The DRCF values for pulmonary adenomas and carcinomas were 1.7 and 3.0, respectively. However, the incidences of these tumours in the controls were 35 and 3 per cent, slightly but not significantly lower than those of the animals that received the extended dose. Angiosarcoma of the liver, the type of tumour known to be the most relevant for human exposure to vinyl chloride (GR87), was not observed under the experimental conditions used.

Littlefield and Gaylor (Lit85) reported on the incidence of liver and bladder tumours in mice treated, at various dose rates, with various doses of the $\mathrm{N}$-substituted 
Table 6 Experiments on tumour incidence following multiple or extended multiple administration of genotoxic carcinogens.

\begin{tabular}{|c|c|c|c|c|c|c|c|}
\hline agent $^{\mathrm{a}}$ & b. act ${ }^{b}$ & species / route & $\begin{array}{l}\text { multiple } \\
\text { exposure }\end{array}$ & $\begin{array}{l}\text { extended multi- } \\
\text { ple exposure }\end{array}$ & effect & $\mathrm{DRCF}$ & ref \\
\hline $\mathrm{OH}-\mathrm{BNN}$ & yes & mouse / p.o. ${ }^{\mathrm{c}}$ & $\begin{array}{l}15,20,30 \mathrm{mg} \\
\text { in } 5 \text { weekly } \\
\text { fractions }\end{array}$ & $\begin{array}{l}15,20,30 \mathrm{mg} \\
\text { in } 10 \text { or } 20 \\
\text { weekly } \\
\text { fractions }\end{array}$ & bladder carcinomas & $\begin{array}{l}0 \text { (at } 15 \mathrm{mg}) \\
0.1 ; 0.3(\text { at } 20 \mathrm{mg}) \\
0.1 ; 0.2(\text { at } 30 \mathrm{mg})\end{array}$ & $\mathrm{McC} 81$ \\
\hline VCM & yes & $\begin{array}{l}\text { mouse / } \\
\text { inhalation }\end{array}$ & $\begin{array}{l}500 \mathrm{ppm} \text { for } \\
1 \mathrm{~h}, 10 \times\end{array}$ & $\begin{array}{l}50 \text { ppm for } \\
1 \mathrm{~h}, 100 x\end{array}$ & $\begin{array}{l}\text { pulmonary adenomas } \\
\text { and carcinomas }\end{array}$ & $\begin{array}{l}1.7 \text { (adenomas) } \\
3.0 \text { (carcinomas) }\end{array}$ & Heh81 \\
\hline 2-AAF & yes & mouse / feed & \multicolumn{2}{|c|}{$\begin{array}{l}60 \text { to } 150 \mathrm{ppm} \text { for } 9 \text { to } 24 \\
\text { months: comparison of groups } \\
\text { that received grossly equal } \\
\text { doses }\end{array}$} & $\begin{array}{l}\text { liver and bladder } \\
\text { tumours }\end{array}$ & $\begin{array}{l}0.4 \text { to } 3.0 \text { (liver) }^{\mathrm{d}} \\
1.0 \text { to } 5.5 \text { (bladder) }^{\mathrm{d}}\end{array}$ & Lit85 \\
\hline
\end{tabular}

\footnotetext{
abbreviations: see list of abbreviations

b need for bioactivation (no = direct carcinogen; yes = indirect carcinogen)

c per os

d $\quad$ see text 5.1 for details of calculation
}

arylamide 2-acetylaminofluorene (2-AAF) in the feed. They re-analysed data from the $\mathrm{ED}_{01}$ study in which groups of 30 to 400 weanling mice were fed 60 to $150 \mathrm{ppm}$ 2-AAF for 9 to 24 months and killed at 18 or 24 months. Comparisons were made at approximately similar doses. Groups dosed at higher rates for fewer months generally had higher incidences than groups receiving similar doses but at lower rates for more months if killed at the same time point. The results were more consistent for bladder tumours than for liver tumours, although similar trends were observed. We noticed that the tumour incidences following low dose rates of 2-AAF were generally very low. Had we used these data, we would have obtained unrealistically high values for the DRCF (up to infinity). Therefore, we estimated the DRCF by considering only the data for groups of animals with at least a 2 per cent incidence of liver or bladder tumours. When these data are used the DRCF values for liver and bladder tumours range from 0.4 to 3.0 and from 1.0 to 5.5 , respectively.

Two more papers have been published on the effects on tumour incidence of differences in the pattern of exposure to genotoxic carcinogens (Tur83, Gre88). However, the lack of accessibility of one paper and the unavailability of the original data for 
review of the other, precluded derivation of DRCF values. The results are, as far as available, mentioned here. Turusov (Tur83) investigated the effects of dose fractionation on the carcinogenicity of 1,2-dimethylhydrazine in mice. The results were reported in Russian, accompanied by a summary in English containing qualitative conclusions only. Fractionation of a dose of 1,2-dimethylhydrazine given subcutaneously exerted different effects on tumour incidences at various sites: a decrease in anal and colon tumour incidence, an increase in vascular liver tumours and renal adenomas and no effects on hepatoma, lung adenoma and uterine sarcoma incidence. As a result the DRCF would be greater than unity, less than unity or equal to unity, respectively. Gregory (Gre88) reviewed dose-response data for benzidine-induced tumours. He reported that a few insults with a relatively low dose of benzidine lead to a higher tumour response per unit dose than does more frequent administration of lower doses, concomitant with a DRCF value greater than unity. Neither the conclusions of Turusov (Tur83) nor those of Gregory (Gre88) allow a more precise derivation of DRCF values.

\subsection{Experiments with genotoxic carcinogens - parameters other than tumour development}

Two papers reported on the effects of dose-rate differences on parameters related to, but other than, tumour incidence. These parameters were the frequency of dominant cataract and recessive specific locus mutations in F1 offspring (Fav88) and that of Sister Chromatid Exchanges (SCE) in peripheral blood lymphocytes and

N-3'-(2-hydroxyethyl)-histidine adducts in haemoglobin (Yag87). The results are summarised in Table 7.

Yager (Yag87) investigated the frequency of SCE in peripheral blood lymphocytes and N-3'-(2-hydroxyethyl)-histidine adducts in haemoglobin in rabbits exposed to the aliphatic cyclic ether, ethylene oxide (ETO), at different dose rates. The animals were exposed to either $1500 \mathrm{ppm}$ twice daily for $15 \mathrm{~min}$ or 200 (or 400) ppm for 5 days a week and 6 hours a day until a cumulative dose of $48,000 \mathrm{ppm} \times \mathrm{h}$ was reached. No effects of these dose-rate differences were found on the frequencies of SCE in peripheral blood lymphocytes and N-3'-(2-hydroxyethyl)-histidine adducts in haemoglobin.

Favor et al. (Fav88) treated mice twice with $80 \mathrm{mg} / \mathrm{kg}$ body weight of the nitrosamine, ethylnitrosourea, and compared the incidence of mutations in germ cells with that from previous experiments in which mice were exposed once to $160 \mathrm{mg} / \mathrm{kg}$ body weight. The single-dose exposure increased the incidence of dominant cataract and recessive specific locus mutations by factors of 4.8 and 1.2 , respectively, as compared to the split-dose exposure. 
Table 7 DRCFs based on parameters of genotoxicity other than tumour incidence

\begin{tabular}{|c|c|c|c|c|c|c|c|}
\hline agent $^{\mathrm{a}}$ & b.act ${ }^{b}$ & species / route & short exposure & protracted exposure & parameter & DRCF & ref \\
\hline ETO & no & $\begin{array}{l}\text { rabbit / } \\
\text { inhalation }\end{array}$ & $\begin{array}{l}1500 \mathrm{ppm} \text { for } 15 \\
\text { min, twice daily } \\
\text { for } 64 \mathrm{~d}\end{array}$ & $\begin{array}{l}200 \mathrm{ppm}, 6 \mathrm{~h} / \mathrm{day}, 5 \mathrm{~d} / \mathrm{wk} \text {, } \\
\text { for } 40 \mathrm{~d} \text { (or } 400 \mathrm{ppm} \text {, } \\
6 \mathrm{~h} / \mathrm{day}, 5 \mathrm{~d} / \mathrm{wk} \text { for } 20 \mathrm{~d} \text { ) }\end{array}$ & $\begin{array}{l}\mathrm{SCE}^{\mathrm{c}} \\
\text { histidine-adducts }\end{array}$ & $\begin{array}{l}1 \\
1\end{array}$ & Yag87 \\
\hline ENU & no & mouse / i.p. & $\begin{array}{l}1 \times 160 \mathrm{mg} / \mathrm{kg} \\
\text { body weight }\end{array}$ & $\begin{array}{l}2 \times 80 \mathrm{mg} / \mathrm{kg} \text { body } \\
\text { weight, } 2 \mathrm{~d} \text { apart }\end{array}$ & $\begin{array}{l}\operatorname{DOCM}^{\mathrm{c}} \\
\mathrm{RSLM}^{\mathrm{c}}\end{array}$ & $\begin{array}{l}4.8 \\
1.2\end{array}$ & Fav88 \\
\hline DCM & yes & not reported & $\begin{array}{l}\text { ranging from } 10 \\
\text { ppm for } 1 \text { min to } \\
8000 \text { ppm for } 8 \mathrm{~h}\end{array}$ & $\begin{array}{l}\text { 'over a very long time } \\
\text { period' }\end{array}$ & $\begin{array}{l}\text { dose-dependent } \\
\text { bioactivation }\end{array}$ & 1.0 to 3.2 & Hat90 \\
\hline
\end{tabular}

Abbreviations of compounds: see list of abbreviations

b Need for bioactivation (no = direct carcinogen; yes = indirect carcinogen)

c DOCM: dominant cataract mutation; RSLM: recessive specific locus mutation; SCE: sister chromatid exchange

d $\quad 1 \times 160 \mathrm{mg} / \mathrm{kg}$ : historical data set; $2 \times 80 \mathrm{mg} / \mathrm{kg}$ : present data set

Should the above parameters be used to substitute for the tumour incidence in the DRCF, the value of the DRCF would vary from 1 to 4.8 .

\section{$5.4 \quad$ Conclusions}

None of the experiments with genotoxic carcinogens reported on in this chapter addressed the comparison of the cancer risks associated with instantaneous exposure to a high dose and lifelong exposure to a low dose, the key question posed in this report. As a consequence, our conclusions should be regarded as indicative only. The studies discussed in 5.1 have in common that the effect of a single dose is compared with that of multiple ones. The studies differ, however, with regard to numerous other aspects of their design, for instance the type(s) of tumour, number of animals used, dose(s) of the substance applied, extent to which the dose was fractionated and protracted, treatment (or absence of treatment) with a tumour promotor, age at the first (or only) exposure, and the timepoint at which the data were obtained. They also differ with regard to the substance under investigation. The studies discussed in 5.2 and 5.3, leading to DRCF values for short-term exposure and DRCF values based on parameters other than, but related to, tumour formation are also heterogeneous with regard to design and 
substance under investigation. The different compounds studied and the many differences in design may at least partly explain the variation encountered among the values of the DRCF, i.e. a spread between 0 and 8.3 . 


\section{Data on ionising radiation}

Ionising radiation is a 'physical carcinogen' (BEIR90). Genotoxic chemicals as well as ionising radiation have the potential to damage DNA and to cause cancer, although there are differences between the mechanisms of their respective genotoxic actions (Car88). As far as DNA mutation detected with cytogenetic techniques is concerned, ionising radiation and chemicals cause different mutations. Ionising radiation induces chromosome-type aberrations in the $\mathrm{G}_{0}$ and $\mathrm{G}_{1}$ phases of the cell cycle, both chromosome- and chromatid-type aberrations in the $\mathrm{S}$ phase and chromatid-type aberrations in the $\mathrm{G}_{2}$ phase. Chemical mutagens induce mostly chromatid-type aberrations, due to the type of DNA lesions induced which have to pass through the $\mathrm{S}$ phase in order to be transformed into detectable aberrations (Car88).

As both chemicals and ionising radiation have genotoxic effects, it is useful to compare the effects of differences in dose rate of chemicals and ionising radiation. However, ionising radiation will not be discussed here in extenso; this would be beyond the scope of the present report. The relevant data are reported below in abridged form, based mainly on a recent report by Kal and Jansen, published by the Health Council of the Netherlands (Kal90). The data, summarised in Table 8, concern low linear energy transfer (LET) radiation ( $\beta$ - and $\gamma$-radiation) and high-LET radiation (e.g. $\alpha$-radiation).

Ultraviolet (UV) radiation, a certain form of non-ionising radiation, is also a physical carcinogen. It is not discussed in this report, however, for the following reason. In contrast to chemicals and ionising radiation UV radiation causes specific DNA mutations (pyrimidine dimers, Set66), and UV-induced tumour formation might 
Table 8 Ionizing radiation: DREFs.

\begin{tabular}{|c|c|c|c|}
\hline source of information & parameter & $\mathrm{DREF}^{\mathrm{a}}$ & refs \\
\hline \multirow[t]{3}{*}{ low-LET /animal } & & 2 to 10 & NCRP80 \\
\hline & & 2 to 10 & UN88 \\
\hline & & 3 & NRPB88 \\
\hline low-LET/in vitro ${ }^{c}$ & $\begin{array}{l}\text { cell transformation, point mutations, } \\
\text { chromosomal aberrations }\end{array}$ & 1 to 3 & Kal90 \\
\hline \multirow[t]{2}{*}{ low-LET/animals ${ }^{\mathrm{c}}$} & life shortening & 0.8 to 5 & Kal90 \\
\hline & tumour incidence & 1 to $8^{\mathrm{d}}$ & Kal90 \\
\hline \multirow[t]{4}{*}{ low-LET/humans ${ }^{\mathrm{c}}$} & leukemia & 2.1 & Kal90 \\
\hline & non-leukemia cancers & $\geq 1.3$ & Kal90 \\
\hline & thyroid tumours & $1 ; \geq 4$ & Kal90 \\
\hline & mammary tumours & 2.6 to 3 & Kal90 \\
\hline \multirow[t]{2}{*}{ low-LET/humans } & leukemia & 2.1 & BEIR90 \\
\hline & non-leukemia cancers & ca. 1 & BEIR90 \\
\hline \multirow[t]{6}{*}{ low-LET/animal } & specific locus mutations & 3 to $10(5)^{e}$ & BEIR90 \\
\hline & reciprocal translocations & 5 to $10(5)$ & \\
\hline & life shortening & 3 to $10(4)$ & BEIR90 \\
\hline & tumour incidence & 1 to $10(4)$ & \\
\hline & & & BEIR90 \\
\hline & & & BEIR90 \\
\hline high-LET ${ }^{f}$ & $\begin{array}{l}\text { 'Dose-rate effect is less than for low-LET, ... dose } \\
\text { protraction may increase cancer incidence in some } \\
\text { situations' }\end{array}$ & - & BEIR90 \\
\hline
\end{tabular}

a $\quad$ DREF = Dose-Rate Effectiveness Factor: 'a factor by which the effect caused by a specific dose of radiation changes at low as compared to high dose rates' (BEIR90)

b low-LET = low Linear Energy Transfer ionising radiation

c conclusion: a DREF between 1.5 and 2.5 is 'a reasonable choice' (Kal90)

a one exceptionally high value of 66 excluded

d range (single best estimate in brackets)

f high-LET = high Linear Energy Transfer ionising radiation 
depend on partial impairment of the immune system (Kri90).

\subsection{Low-LET ionising radiation}

There is a wealth of data on the tumourigenic effect of differences in dose rate of lowLET ionising radiation. The relative risk of different exposure patterns to ionising radiation has been expressed as Dose Rate Effectiveness Factor (DREF, BEIR90). The DREF is 'a factor by which the effect caused by a specific dose of radiation changes at low as compared to high dose rates' (BEIR90). This factor has been used to estimate, based on the data available, the cancer risk associated with low dose rates. In the case of human exposure the data concern short-term exposure to high dose rates (e.g. Japanese atomic bomb survivors); DREF values were derived from these data by modelfitting. In the case of experimental data, however, a DREF could be calculated from results obtained with both high and low dose rates.

The National Council on Radiation Protection and Measurements (NCRP) in the USA evaluated data obtained in the period 1963-1979 (NCRP80). Only the data obtained with laboratory animals allowed calculation of DREF values. The NCRP derived values ranging from 2 to 10 from these data. The United Nations Scientific Committee on the Effects of Atomic Radiation, UNSCEAR (UN88), and the British National Radiological Protection Board, NRPB (NRPB88), have based their evaluations on the data in NCRP80. The UNSCEAR (UN88) agrees with the conclusions of NCRP. The NRPB (NRPB88) concluded that a value of 3 is appropriate for the purpose of radiation protection.

Kal and Jansen (Ka190) examined, on request of the Health Council of the Netherlands, whether more recent publications (from the period 1979-1989) concerning in vitro cell transformation, gene mutations, chromosomal aberrations, and tumour induction in humans and animals could provide additional information on the value for the DREF of low-LET radiation (cf. Table 8). They calculated a DREF ranging from 1 to 3 from data based on various in vitro parameters (cell transformation, point mutations and chromosomal aberrations). Two high values were found: 5.4 and 13 . The reciprocal mean, median and geometric mean calculated from the in vitro data are 1.7, 1.7 and 2.4, respectively.

Kal and Jansen also calculated values of the DREF from results obtained with lowLET radiation in laboratory animals. When life-shortening due to tumour growth was used as parameter, values from 0.8 to 5 were derived. The reciprocal mean, median and geometric mean are 1.8, 2.1 and 2.2, respectively. Values based on tumour incidences varied from 1 to 8 , if one exceptional, high value was excluded. This value (66) stemmed from induction of mammary tumours at very low dose rates. The reciprocal 
mean, median and geometric mean of DREFs based on animal data are 2.1, 2.3 and 7.1 , respectively.

Kal and Jansen concluded that the most recent data on human exposure to ionising radiation derived from the atomic bomb survivors in Japan, point to a DREF value of 2.1 for leukaemia and at least 1.3 for other tumours. In other epidemiological studies DREF values of 1 were found for thyroid and 2.6 and 3 for mammary tumours; in the case of thyroid tumours caused by radioactive iodine $\left({ }^{131} \mathrm{I}\right)$ the DREF is at least 4 . Overall, the reciprocal mean, median and geometric mean of DREF values based on epidemiological data are $1.9,2.3$ and 2.3 , respectively.

Combination of the recent experimental data reviewed by Kal and Jansen with earlier data from NCRP80 led to DREFs for life-shortening and tumour induction of 5.5, 2.5 and 2.5 for the reciprocal mean, median and geometric mean, respectively. These values were $2.5,1.7$ and 1.7, respectively, for the combined in vitro data (Ka190). Kal and Jansen felt that for the purpose of extrapolation from high doses of low-LET radiation to low doses a low weight should be attributed to high DREF values and vice versa, since a high DREF value may potentially lead to underestimation of the risk at low doses. They concluded that if this approach is chosen, a DREF of 1.5 to 2.5 is a "reasonable choice" for extrapolation from high to low dose rates.

The BEIR-V committee (BEIR90) evaluated the data available for a DREF for low LET radiation and stated that: "there are scant human data that allow an estimate of the DREF"; a DREF of 2.1 was established for leukaemia, while for most other types of cancer the DREF was near unity. BEIR-V also calculated DREF values from the more extensive animal data. The range of values observed in animal studies has an upper limit of 10 for each of four different endpoints, one of which is tumour incidence. The single best estimates of the DREF of these endpoints are 4 to 5 .

The Committee on Radiation risk of the Health Council of the Netherlands used the report of Kal and Jansen when preparing an advisory report on the effects of ionising radiation (GR91). They agreed with the conclusions reached by Kal and Jansen (Kal90) and BEIR-V (BEIR90), that the data from the atomic bomb survivors in Japan provide evidence that the DREF of leukaemia is 2.1 and that of all other tumours about unity.

\subsection{High-LET ionising radiation}

There are few studies on the effects of differences in dose rate of high-LET radiation (cf. Table 8). In contrast to the dose-rate effect of low-LET ionising radiation, "the dose-rate effect of high-LET ionising radiation is much reduced (..... ) there is some evidence that, for high-LET radiation, protracting an exposure may lead to an increase in the induction of cancer and mutations in some situations" (BEIR90). This 
conclusion is in line with that of Kal and Jansen (Kal90), who concluded that at low doses and low dose rates cell transformation in vitro is enhanced, an observation for which there is no clear explanation. Results from animal experiments also suggest that dose protraction enhances the tumour incidence. Kal and Jansen concluded that a DREF greater than unity is not justified in the case of high-LET radiation.

\subsection{Conclusion}

Kal and Jansen (Ka190) concluded that the reciprocal mean and median DREF of lowLET ionising radiation lie between 1.5 and 2.5. They also concluded that the few data available for the effects of dose-rate differences of high-LET ionising radiation do not justify a DREF greater than unity. We infer that the values of the DREF of ionising radiation range from 1 to 10 . 


\section{Additional data}

This chapter considers several papers which may contribute knowledge relevant to risk assessment of peak exposure to carcinogens, but which do not allow calculation of DRCF values. These papers refer to kinetics, metabolism and DNA repair.

Several chemicals are carcinogenic only after they have been activated metabolically (Kla86). The amount of reactive metabolite formed might not be linearly related to the dose over the whole dose range because, at high doses, the enzyme that forms the reactive metabolite might become saturated or depletion of co-substrate might occur. After the reactive metabolite is formed, it is often detoxified by a second enzyme, which can also be saturated. The reactive metabolites not detoxified by these detoxification pathways might bind to DNA. However, the resulting DNA lesions can be repaired by various DNA repair systems, that may also become saturated. Incorporation into quantitative risk assessment of knowledge regarding these aspects of metabolism would allow more accurate assessment of the risk of exposure to chemicals. A recently developed scientific method: physiologically-based pharmacokinetic (PBPK) modelling, enables incorporation of such knowledge into quantitative risk assessment.

A PBPK model describes mathematically the interrelationships among the mechanistic determinants of the health effects of interest. It enables estimation of the 'biologically effective dose' and use of this dose rather than the dose administered for risk assessment (And92). In the case of a genotoxic agent the biologically effective dose could be the concentration in the blood of reactive metabolites formed or the amount bound to DNA locally. 
A well-documented example of the application of a PBPK model to quantitative risk assessment of exposure to a compound is the model used for dichloromethane (DCM) (And87). The data obtained with this model provide a good illustration of how PBPK models may improve quantitative risk assessment. Anderson and colleagues (And87) used the model to calculate from data on DCM metabolism two types of 'internal dose' as substitutes for the biologically effective dose: 1) the tissue dose of DCM as Area Under the concentration-time Curve (AUC) in target tissues (liver, lung), 2) the amount of DCM metabolised in target tissues via two metabolic pathways. The tumour incidence in the target tissues of mice appeared to correlate well with the AUC of the tissue and the amount of DCM metabolised in the tissue by one of the two metabolic pathways. Using these types of internal dose, the target tissue doses in humans exposed to low concentrations of DCM were estimated to be 140 - to 170-fold lower (inhalation) or 50- to 210-fold lower (drinking water) than would have been expected from conventional risk assessment methods. This suggests that application to quantitative risk assessment of the biologically effective dose instead of the administered dose leads to a 50- to 210 -fold reduction of risk overestimation. The risk reduction is due to 1) saturation of relevant metabolic enzymes at the doses tested in mice, 2) lower levels of these metabolic enzymes in humans than in mice. The above results suggest that application of a PBPK model to quantitative risk assessment could lead to a more accurate assessment of risk.

Bailer and Hoel (Bai89) developed a PBPK model for more accurate assessment from animal experiments of the cancer risk associated with exposure to benzene. For this purpose, using data on benzene metabolism they obtained the internal dose by calculating the AUC over all tissue and fluid samples collected for two toxic metabolites of benzene. Furthermore Bailer and Hoel modelled the relationship between the administered and the internal doses. They applied the model to the NTP carcinogenicity study of benzene in rats en mice. They calculated AUC following various exposure regimens to an equal dose and obtained similar results with the two benzene metabolites. The AUC of each metabolite was higher in mice treated at low dose rates than in mice treated with benzene at high dose rates; the opposite was found in rats. These findings are consistent with saturation of metabolic pathways in mice and lack of saturation in rats. Their implication for risk assessment of peak exposure is the following: if human metabolism is clearly saturable, like mouse metabolism, long-term low-dose exposure should be weighted more heavily than short-term, high-dose exposure. The opposite weighting should be applied if human metabolism resembles rat metabolism.

Recently, Hattis (Hat90) recognised that exposure to high dose rates of carcinogens may lead to saturation of metabolic processes and, as a consequence, to a carcinogenic risk greater or less than that associated with low dose rates. According to Hattis, saturation of a detoxification or a DNA repair process has the potential to create a risk 
which is as much as squared when the dose is delivered in a peak, and if more than one process becomes fully saturated, their effects can be compounded. The author used as examples for his statement on the effect of saturation of metabolic processes on carcinogenic risk the following findings

- vinyl chloride: flattening of the tumour response at high doses, although toxicity was not excluded as cause of the flattening (Mal75)

- a set of aliphatic chlorinated hydrocarbons: saturation of overall metabolism ranging from no detectable to full saturation (Mit85)

- a set of $\mathrm{N}$-nitroso compounds: saturation of bioactivation pathways leading to fewer single-strand breaks in rat liver DNA (Bra87)

- DCM: incorporation of pharmacokinetic data into DRCF values (cf. Table 7; the original data on DCM, cited by Hattis, were not available to us).

Hattis concluded that the value of the DRCF of DCM is 3.2 at most. The examples reviewed by Hattis support the notion that peak exposure may lead to risks either greater or less than those associated with exposure to low doses.

Magee and Barnes reported a difference in site of tumour formation ('organotropism') following treatment with a single high dose or multiple low doses of dimethylnitrosamine (DMNA) (reviewed in Mag67). Administration to rats of one high dose of DMNA induced tumours in the kidney, whereas administration of repeated small doses or prolonged feeding resulted in liver tumours. Nicoll and co-workers (Nic75) elucidated the mechanism underlying this regimen-dependent organotropism of DMNA. They observed that the DNA adduct, $0^{6}$-methylguanine, one of the reaction products of DMNA with DNA, is much longer lived in kidney DNA after a high dose of DMNA than after a smaller dose or in liver DNA after either dose. The differences in ability of the kidney and the liver to remove a specific DNA adduct might be explained by inhibition or saturation of the DNA-repair enzyme responsible in the kidney at the single high dose.

The data discussed in this chapter show that saturation of metabolic processes and DNA repair may crucially influence the DRCF for peak exposure to genotoxic carcinogens. The experiments on the basis of which DRCFs for genotoxic chemicals were calculated were performed with chemically heterogeneous compounds, most of which belong to the classes of $\mathrm{N}$-nitroso compounds or PAHs. All experiments but one (Jos70, using MNU) reported in 5.1 and 5.2 were performed with indirect carcinogens, i.e. compounds needing metabolic activation to be able to react with DNA. The results of these experiments may have been influenced by saturation of enzymes responsible for bioactivation, detoxification or DNA repair. The results with MNU (Jos70) and those for parameters other than tumour incidence (Fav88, Yag87) were obtained with 
direct carcinogens, i.e. compounds which are carcinogenic without metabolic activation. Thus, these results are independent of bioactivation, but may have been influenced by saturation of detoxification and DNA-repair enzymes.

The data in this chapter do not allow the correction of the DRCF values derived in chapter 5 because there was no question of equal doses with the exposure regimens compared, and because the data may be specific for the substance in question. If the data are specific, the data in this chapter only allow qualitative general conclusions. If a single high dose should lead to saturation, depletion or inhibition of any process protecting against tumour development, e.g. DNA repair, non-enzymatic or enzymatic detoxification, it would give rise to an increased chance of DNA mutation and a higher value of the DRCF. On the other hand, should the single high dose lead to saturation, depletion or inhibition of any process potentially causing tumour development, like excretion and enzymatic bioactivation, it would result in a decreased chance of DNA mutation and a lower value of the DRCF. The net effect of a high dose on the DRCF of peak exposure depends on the relative contributions of all the processes contributing to these protecting and toxifying factors. This influence can only be quantified for each compound separately using relevant metabolic data for the compound in question. 


\section{General discussion}

The data reviewed in the present report show that peak exposure to a genotoxic chemical may induce cancer. The data also show that the DRCF values for genotoxic carcinogens calculated from experimental studies vary. These values vary from zero to 8.3. Theoretical calculations of DRCF values and derivation of DREF values from data on ionising radiation also lead to ranges of values. Theoretical calculations result in DRCF values that range from zero to 7.1. Epidemiological and experimental data on the effects of ionising radiation indicate that the DREF ranges from 1 to 10 .

An important reason for the variation in DRCF values for genotoxic carcinogens is that the experiments we have based our conclusion on, experiments with genotoxic carcinogens, are limited in number and do not comply exactly with comparison of peak exposure with lifelong exposure to low doses (cf. 5.4). Furthermore, the experiments differed as to several aspects, as discussed in chapters 5 and 7.

Even though variations in the design of the experiments with the chemicals reviewed may explain the range of DRCF values observed, the data in chapter 7 suggest that there is no universal DRCF value, but that the DRCF value is compound-specific. In view of the limitations of the data we regard a DRCF value of 10 appropriate as a 'default' value if no or insufficient data are available to estimate a compound-specific value of the DRCF.

The absolute cancer risk associated with peak exposure to a genotoxic carcinogen cannot be determined exactly; it can only be estimated. The risk associated with peak exposure can be estimated using a DRCF: it can be expressed relative to the risk of 
lifelong exposure to a low dose if the latter risk has been estimated. Estimation of this risk is based on assumptions which cannot be verified (cf. chapter 1).

The relative risk associated with exposure patterns that differ only slightly from peak exposure, such as several accidental releases in a few days, months or years, or a high exposure lasting for several days (short-term exposures) may also be estimated. In fact, the few data available for short-term exposures (cf. 5.2) have been used to derive the maximum value of the DRCF for peak exposure. Therefore, we propose to apply a DRCF value of 10 for assessment of the maximum risk associated with these exposure patterns as well.

The maximum risk of peak exposure to genotoxic carcinogens can be calculated according to the following formula:

$$
\text { Risk }=10^{-6} \times I D \times\left(D_{\text {one/million }}\right)^{-1} \times 25,600^{-1} \times 10 \approx 4 \times 10^{-10} \times I D \times\left(D_{\text {one/million }}\right)^{-1}
$$

in which $D_{\text {onemmillion }}$ is the daily dose corresponding to a politically accepted cancer risk in the general population of 1 in $10^{6}, I D$ is the dose of the peak exposure, 10 is the DRCF and 25,600 is the average number of days in a lifetime.

This formula implies that if $I D$ is equal to $25,600 \times \mathrm{D}$ the cancer risk of peak exposure is 1 in $10^{5}$ at most. To limit the risk of peak exposure to 1 in $10^{6} I D$ should not exceed $2560 \times D_{\text {one/million }}$.

Whether an elevated cancer risk would actually be the result of peak exposure to a genotoxic compound depends on the level of the peak exposure and the level of the substance in question causing acute toxic effects. Should the level of the peak exposure approach the level known to cause acute effects, like lethality, these effects would prevail (ECE91, appendix B).

The present report focuses on risk assessment of peak exposure to genotoxic carcinogens. A similar assessment for non-genotoxic carcinogens would complete the risk assessment of peak exposure to carcinogens. 


\section{Suggestions for future research}

The data available only allowed a 'worst case' value to be established for the DRCF of peak exposure to genotoxic chemical carcinogens. Experimental data are needed for a more accurate estimate of the DRCF of peak exposure to a given genotoxic chemical carcinogen. Some general suggestions can be made for future experiments.

A topic needing further investigation is the dependence of the DRCF on the dose. It is advisable to investigate whether a genotoxic carcinogen induces tumours in experimental animals if it is administered as a single high dose or as a few high doses just below the $L_{50}$. A dose just below the $L_{5}$ would best represent peak exposure: it would ensure that the dose is as high as possible but still lacks acute toxicity. Priority should be given to experiments with substances which are most likely to be involved in accidental releases at high doses and to affect a great number of people.

Another important matter for investigation is the influence of the age at exposure to a single high dose. Single-dose carcinogenicity should be investigated by administration of the test substance at various ages.

A third topic for investigation is the timepoint of evaluation, since the studies of Druckrey and colleagues (Dru67) have suggested that the DRCF might be higher if the interval between the start and the end of an experiment were shorter. When the tumour incidence due to peak exposure is being compared to that due to long-term exposure to low doses, the experiment should preferably be of the same duration as chronic carcinogenicity studies, representing lifelong exposure as closely as possible.

Furthermore, experiments with direct genotoxic carcinogens designed to shed light on the kinetics of DNA repair in vivo at high and low dose rates would be very useful. 
Experiments with indirect genotoxic carcinogens designed to assess the contribution of biotransformation are important as well. Last but not least, risk assessment of peak exposure (to carcinogens) as well as (carcinogenic) risk assessment in general would benefit from the further development of PBPK models. 


\section{References}

\footnotetext{
Ale89 Alexeeff GV, Lipsett MJ, Kizer KW. Problems Associated with the Use of Immediately Dangerous to Life and Health (IDLH) Values for Estimating the Hazard of Accidental Chemical Releases. Am Ind Hyg Assoc J 1989;50: 598-605.

Alt73 Althoff J, Pour P, Cardesa A, et al. Comparative Studies of Neoplastic Response to a Single Dose of Nitroso Compounds. 2. The effect of N-dibutylnitrosamine in the Syrian Golden Hamster. Z Krebsforsch 1973; 79: 85-9.
}

And87 Andersen ME, Clewell HJ, Gargas ML, etal. Physiologically based pharmacokinetics and the risk assessment process for methylene chloride. Toxicol Appl Pharmacol 1987; 87: 185-205.

And92 Andersen ME, Krishnan K, Conolly RB, et al. Mechanistic toxicology research and biologically-based modelling: partners for improving quantitative risk assessments. CIIT Activities 1992; 12: 1-7.

Bai89 Bailer AJ, Hoel DG. Metabolite-Based Internal Doses Used in a Risk Assessment of Benzene. Environ Health Persp 1989; 82: 177-84.

BEIR90 Committee on the Biological Effects of Ionizing Radiation. Health effects of exposure to low levels of ionizing radiation. Washington, DC: National Academy Press, 1990.

Ber89 Bertazzi P A. Industrial disasters and epidemiology. Scand J Work Environ Health 1989; 15: 85-100.

Bro83 Brown CC. Learning about toxicity in humans from studies on animals. Chemtech. 1983; June, 350-8.

Bry43 Bryan WR, Shimkin MB. Quantitative Analysis of Dose-Response Data Obtained With Three Carcinogenic Hydrocarbons in Strain C3H Male Mice. JNCI 1943; 3: 503-31.

Buc93 Bucher JR, Melnick RL, Hildebrandt PK. Lack of carcinogenicity in mice exposed once to high concentrations of 1, 3-butadiene. J Natl Cancer Inst 1993; 85: 1866-7.

Car88 Carrano AV, Natarajan AT. Considerations for population monitoring using cytogenetic techniques. Mutat Res 1988; 204: 379-406. 

Exposures. Risk Anal 1988; 8: 223-30.

COT86 Committee on Toxicology. Criteria and Methods for Preparing Emergency Exposure Guidance Level (EEGL), Short-Term Public Emergency Guidance Level (SPEGL), and Continuous Exposure Guidance Level (CEGL) Documents. 1986; National Academy Press, Washington D.C.

Cru84 Crump KS, Howe RB. The Multistage Model with a Time- Dependent Dose Pattern: Applications to Carcinogenic Risk Assessment. Risk Anal 1984; 4: 163-76.

Day80 Day NE, Brown CC. Multistage Models and Primary Prevention of Cancer. JNCI 1980; 64: $977-89$.

Dru64 Druckrey H, Steinhoff D, Preussmann R, et al. Erzeugung von Krebs durch eine einmalige Dosis von Methylnitroso-Harnstoff und verschiedenen Dialkylnitrosaminen an Ratten. Z Krebsforsch 1964; 66: 110.

Dru67 Druckrey H. Quantitative Aspects in Chemical Carcinogenesis. UICC Monographs Series 1967; 7: 60-77.

ECE91 ECETOC. Emergency exposure indices for industrial chemicals, Technical report, No. 43. Brussels, March 1991.

EPA86 Environmental Protection Agency. Guidelines for carcinogen risk assessment. Federal Register 1986; 51: 33992-4003.

Fav88 Favor J, Neuhauser-Klaus A, Ehling UH. The effect of dose fractionation on the frequency of ethylnitrosourea-induced dominant cataract and recessive specific locus mutations in germ cells of the mouse. Mut Res 1988; 198: 269-75.

Fer91 Ferguson JS, Alarie Y. Long term pulmonary impairment following a single exposure to methyl isocyanate. Toxicol Appl Pharmacol 1991; 107: 253-68.

GR78 Gezondheidsraad. Advies inzake de beoordeling van carcinogeniteit van chemische stoffen. Den Haag: Gezondheidsraad 1978; publikatie nr 1978/19.

GR88 Gezondheidsraad. De beoordeling van de carcinogeniteit van chemische stoffen II. Den Haag: Gezondheidsraad 1988; publikatie nr 1988/04.

GR92 Gezondheidsraad: Commissie Stralingsrisico's. Stralingsrisico's. Evaluatie van wetenschappelijke gegevens over de gezondheidsrisico's van blootstelling aan ioniserende straling ten behoeve van normstelling. Den Haag: Gezondheidsraad, 1993; publikatie nr 1991/22.

Gra91 Gray R, Peto R, Brantom P, et al. Chronic nitrosamine ingestion in 1040 rodents: the effect of the choice of nitrosamine, the species studied, and the age of starting exposure. Cancer Res 1991; 51: 6470- 91.

Gre88 Gregory AR. Species Comparisons in Evaluating Carcinogenicity in Humans. Regulatory Tox Pharmacol 1988; 8: 160-90.

Hat90 Hattis D. Pharmacokinetic Principles for Dose-Rate Extrapolation of Carcinogenic Risk from Genetically Active Agents. Risk Anal 1990; 10: 303-16.

HCN87 Health Council of the Netherlands (Gezondheidsraad): Committee on the Evaluation of the Carcinogenicity of Chemical Substances. A scientific basis for the risk assessment of vinyl chloride. Regul Toxicol Pharmacol 1987; 7: 120-7. 
HCN94 Health Council of the Netherlands (Gezondheidsraad): Committee on the Evaluation of the Carcinogenicity of Chemical Substances. Risk assessment of carcinogenic chemicals in the Netherlands. Regul Toxicol Pharmacol 1994; 19: 14-30.

Hec83 Hecht SS, Adams JD, Numoto S, et al. Induction of respiratory tract tumors in Syrian golden hamsters by a single dose of 4-(methylnitrosamino)-1- (3-pyridyl)-1-butanone (NNK) and the effect of smoke inhalation. Carcinogenesis 1983; 4: 1287-90.

Hec89 Hecht SS, Morse MA, Amin S, et al. Rapid single-dose model for lung tumor induction in A/J mice by 4(methylnitrosamino)-1-(3-pyridyl)-1-butanone and the effect of diet. Carcinogenesis 1989; 10: 1901-4.

Heh81 Hehir RM, McNamara BP, McLaughlin JJr, e.a. Cancer Induction Following Single and Multiple Exposures to a Constant Amount of Vinyl Chloride Monomer. Environ Health Perspect 1981; 41: 63-72.

ICRP91 International Commission on Radiogical Protection. Risk associated with ionising radiations. In: Annals of the ICRP. Oxford: Pergamon Press, 1991; Vol 22.

Ill89 Illing HPA. Assessment of Toxicity for Major Hazards: Some Concepts and Problems. Human Toxicol 1989; 8: 369-74.

IUPAC93 International Union of Pure and Applied Chemistry. Clinical Chemistry Division. Commission on To; xicology. Glossary for chemists of terms used in Toxicology. Pure Appl Chem 1993; 65: 2003-2122.

Ive64 Iversen $\mathrm{OH}$, Iversen U. A study of epidermal tumourigenesis in the hairless mouse with single and with repeated applications of 3-methylcholanthrene at different dosages. Acta Pathol Microbiol Scandinav 1964; 62: 305-14.

Ive86 Iversen OH. Carcinogenesis Studies with Benzoyl Peroxide (Panoxyl Gel 5\%). J Invest Dermatol 1986; 86: $442-8$.

Ive88 Iversen OH. Skin tumorigenesis and carcinogenesis studies with 7,12-dimethylbenz[a]anthracene, ultraviolet light, benzoyl peroxide (Panoxyl gel 5\%) and ointment gel. Carcinogenesis 1988; 9: 803-9.

Ive91 Iversen $\mathrm{OH}$. The skin tumorigenic and carcinogenic effects of different doses, numbers of dose fracti- ons and concentrations of 7,12-dimethylbenz[a]anthracene in acetone applied on hairless mouse epidermis. Possible implications for human carcinogenesis. Carcinogenesis 1991; 12: 493-502.

Jos70 Joshi VV, Frei JV. Effects of Dose and Schedule of Methylnitrosourea on Incidence of Malignant Lymphoma in Adult Female Mice. J Nat Cancer Inst 1970; 45: 335-9.

Kal90 Kal HB, Jansen JTM. Stralingsrisico's: dosisreductiefactor. Gegevens over de effectiviteit van ioniserende straling bij lage doses. Den Haag: Gezondheidsraad, 1990; publikatie nr A90/9.

Kla86 Klaassen CD. Principles of toxicology. In: Casarett and Doull's Toxicology - the basic science of poisons. 1986, 11-32.

Kod87 Kodell RL, Gaylor DW, Chen JJ. Using Average Lifetime Dose Rate for Intermittent Exposures to Carcinogens. Risk Anal 1987; 7: 339-45.

Kri90 Kripke ML. Review. Effects of UV radiation on tumor immunity. J Natl Cancer Inst 1990; 82: 1392-5.

Lit85 Littlefield NA, Gaylor DW. Influence of total dose and dose rate in carcinogenicity studies. J Tox Environ Health 1985; 15: 545-50.

Lub90 Lubin JH, Qiao Y 1, Taylor PR, et al. Quantitative Evaluation of the Radon and Lung Cancer Association in a Case Control Study of Chinese Tin Miners. Cancer Res 1990; 50: 174-80. 
Mag59 Magee PN, Barnes JM. The experimental production of tumours in the rat by dimethylnitrosamine. Acta Un int Cancer 1959; 15: 187.

Mag67 Magee PN, Barnes JM. Carcinogenic nitroso compounds. Adv Cancer Res 1967; 10: 163-246.

Mal75 Maltoni C, Lefemine G. Carcinogenicity bioassays of vinyl chloride: current results. Ann NY Acad Sci 1975; 246: 195-218

Mar84 Markovitz A, Crosby WH. A Soil Fumigant, 1,3-Dichloropropene, as Possible Cause of Hematologic Malignancies. Arch Intern Med 1984; 144: 1409-11.

McC81 McCormick DL, Ronan SS, Becci PJ, et al. Influence of total dose and dose schedule on induction of urinary bladder cancer in the mouse by N-butyl-N-(4-hydroxybutyl)nitrosamine. Carcinogenesis 1981; 2: 251-4.

Mit85 Mitoma C, Steeger T, Jackson SE, et al. Metabolic disposition study of chlorinated hydrocarbons in rats and mice. Drug Chem Toxicol 1985; 8: 183-94.

Moh70 Mohr U. Effect of diethylnitrosamine in the respiratory system of Syrian golden hamsters. In: Nettesheim P, Hanna MG Jr, Deatherage JW Jr. (Eds.) Morphology of experimental respiratory carcinogenesis. 1970; AEC Symposium Series 21: 255-65.

Mur88 Murdoch DJ, Krewski D. Carcinogenic Risk Assessment with Time-Dependent Exposure Patterns. Risk Anal 1988; 8: 521-30.

NCRP80 National Council on Radiation Protection and Measurements. Influence of dose and its distribution in time on dose-response relationships for low-LET radiations. Washington: National Council on Radiation Protection and Measurements, 1980; report nr 64.

Nic75 Nicoll JW, Swann PF, Pegg AE. Effect of dimethylnitrosamine on persistence of methylated guanines in rat liver and kidney DNA. Nature 1975; 254: 261-2.

NRPB88 Stather JW, Muirhead CR, Edwards AA, et al. Health effect models developed from the 1988 UNSCEAR report. NRPB REPort R 226. National Radiological Protection Board, 1988.

Pay60 Payne WW, Hueper WC. The Carcinogenic Effects of Single and Repeated Doses of 3,4-Benzpyrene. Amer Ind Hyg Assoc J 1960; $21: 350-5$.

Pet91a Peto R, Gray R, Brantom P, e.a. Effects on 4080 rats of chronic ingestion of N-nitrosodiethylamine or Nnitrosodimethylamine: a detailed dose-response study. Cancer Res 1991; 51: 6415-51.

Pet91b Peto R, Gray R, Brantom P, et al. Dose and time relationships for tumor induction in the liver and esophagus of 4080 inbred rats by chronic ingestion of $\mathrm{N}$-nitrosodiethylamine or $\mathrm{N}$-nitrosodimethylamine. Cancer Res 1991; 51: 6452-69.

Saf72 Saffiotti U, Montesano R, Sellakumar AR, et al. Respiratory Tract Carcinogenesis in Hamsters Induced by Different Numbers of Administrations of Benzo(a)pyrene and Ferric Oxide. Cancer Res 1972; 32: 1073-81.

Sal56 Salaman MH, Roe FJC. The development of malignant tumours of mouse skin after "initiating" and "promoting" stimuli. IV. Comparison of the effects of single and divided initiating doses of 9,10-dimethyl-1,2-benzanthracene (DMBA). Br J Cancer 1956; 10: 79-88. 

gene Wirkung verschiedener N-Nitrosoverbindungen nach einmaliger bzw. langzeitiger Applikation bei Ratten. J Cancer Res Clin Oncol 1979; 95: 123-7. Setlow RB, Carrier WL. Pyrimidine dimers in ultraviolet-irradiated DNA's. J Mol Biol 1966; 17: 237-54. Shimkin MB, Polissar MJ. Some quantitative observations on the induction and growth of primary pulmonary tumors in strain A mice receiving urethan. JNCI 1955; 16: 75-97.

Shi69 Shimkin MB, Gruenstein M, Meranze DR, et al. The Effects of Schedule and Dose of 7,12- Dimethylben-

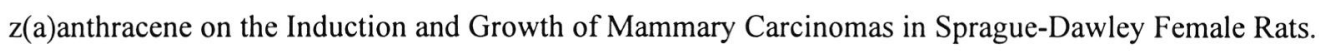
Cancer Res 1969; 29: 503-5.

Sin80 Sinha DK, Dao TL. Induction of Mammary Tumors in Aging Rats by 7,12-Dimethylbenz[a]anthracene: Role of DNA Synthesis During Carcinogenesis. JNCI 1980; 64: 519-21.

Swe91 Swensberg JA, Hoel DG, Magee PN. Mechanistic and statistical insight into the large carcinogenesis bioassays on N-nitrosodiethylamine and N-nitrosodimethylamine. Cancer Res 1991; 51: 6409-14.

Tay75 Taylor HW, Nettesheim P. Influence of administration route and dosage schedule on tumor response to nitrosoheptamethyleneimine in rats. Int J Cancer 1975; 15: 301-7.

Tur83 Turusov VS, Lanko NS, Murovanny AN, et al. Influence of schedule of treatment and route of administration on the carcinogenicity of 1,2-dimethylhydrazine in mice. Vopr Onkol 1983; 29: 59-66.

Tur84 Turusov VS. Influence of dose fractionation on carcinogenicity of chemical compounds. Eksp Onkol 1984; 6: 15-20.

UN88 United Nations Scientific Committee on the Effects of Atomic Radiation. Sources, Effects and Risks of Ionizing Radiation. 1988 report to the General Assembly, with annexes. New York: United Nations, 1988.

Whi70 White MR, Grendon A, Jones HB. Tumor Incidence and Cellularity in Lungs of Mice Given Various Dose Schedules of Urethan. Cancer Res 1970; 30: 1030-6.

Yag87 Yager JW. Effect of concentration-time parameters on sister-chromatid exchanges induced in rabbit lymphocytes by ethylene oxide inhalation. Mut Res 1987; 182: 343-52. 


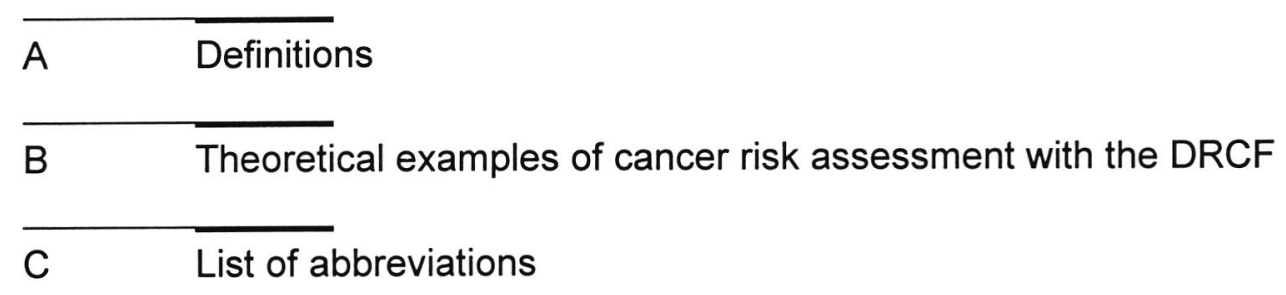

\section{Annexes}




\section{Definitions}

- administered dose

dose the organism is exposed to

- biologically effective dose

dose the target organ is exposed to

- carcinogen

a substance that can cause cancer

- direct carcinogen

a substance which is carcinogenic without metabolic conversion

- dose

the amount of a substance administered per unit mass

- dose rate

the dose of a substance administered per unit time

- $\quad D R C F$

the Dose Rate Correction Factor (DRCF) is a factor by which the tumour incidence caused by a specific dose of chemical carcinogen at low dose rates is multiplied to derive the tumour incidence at high dose rates

- DREF

the Dose Rate Effectiveness Factor (DREF) is 'a factor by which the tumour incidence caused by a specific dose of radiation changes at low as compared to high dose rates' (BEIR90) 
- fractionation

the administration of a given total dose as several smaller doses, separated by intervals of time

- genotoxic carcinogen

a carcinogen capable of irreversible modification of DNA

- indirect carcinogen

a compound which needs metabolic conversion to become carcinogenic

- internal dose

operational substitute for the 'biologically effective dose'

- non-genotoxic carcinogen

a carcinogen not capable of irreversibly modifying DNA

- peak exposure

a single instantaneous exposure (lasting less than 24 hours) to a high dose of a substance

- protraction

the spreading of a dose of a substance over time at a lower dose rate

- tumour incidence

the fraction of animals expressing tumours 
Annex B

\section{Theoretical examples of cancer risk assessment with the DRCF}

Five theoretical examples of the cancer risk associated with peak exposure are given below. Example 1 (cf. chapter 7) is the starting point. In examples 2 to 5 the deviations from example 1 are given in bold-face.

\section{Examples:}

1) if dose $D_{\text {one/million }}$ corresponds to a politically accepted cancer risk of 1 in $10^{6}$ in the general population, the instantaneous dose $I D$ is equal to $25,600 \times D_{\text {onermillion }}$, the $D R C F$ is 10 , the $L D_{s 0}$ is $2,560,000 \times D_{\text {onemillion }}$ (compound with low acute toxicity)

$$
\text { Risk }=10^{-6} \times 25,600 D_{\text {one/million }} \times\left(D_{\text {one/million }}\right)^{-1} \times 25,600^{-1} \times 10=1 / 10^{5}
$$

Thus, if 100,000 people are exposed to an instantaneous dose of $25,600 \times D_{\text {onemmillion }}$, at worst one out of these 100,000 could get cancer as a result of that exposure.

2) if a daily dose $D_{\text {one/million }}$ corresponds to a cancer risk of 1 in $10^{6}$, the instantaneous dose $I D$ is $\mathbf{2 5 6 , 0 0 0} \times D_{\text {one/million }}$ the $D R C F$ is 10 , the $L D_{50}$ is $2,560,000 \times D_{\text {onemillion }}$ (compound with low acute toxicity);

$$
\begin{aligned}
& \text { Risk }=10^{-6} \times I D \times\left(D_{\text {one/million }}\right)^{-1} \times 25,600^{-1} \times 10= \\
& =10^{-6} \times 256,000 \times D_{\text {one/million }} \times\left(D_{\text {one/million }}\right)^{-1} \times 25,600^{-1} \times 10=1 / 10^{4}
\end{aligned}
$$


3) if a daily dose $D_{\text {oneftenthousand }}$ corresponds to a cancer risk of $\mathbf{1}$ in $\mathbf{1 0}^{4}$, the instantaneous dose $I D$ is $25,600 \times D_{\text {onelenthousand, }}$ the $D R C F$ is 10 , the $L D_{50}$ is $2,560,000 \times D_{\text {one/million }}$ (compound with low acute toxicity):

$$
\begin{aligned}
& \text { Risk }=10^{-4} \times I D \times\left(D_{\text {oneltenthousand }}\right)^{-1} \times 25,600^{-1} \times 10= \\
& =10^{-4} \times 25,600 \times D_{\text {oneltenthousand }} \times\left(D_{\text {oneltenthousand }}\right)^{-1} \times 25,600^{-1} \times 10=1 / 10^{3}
\end{aligned}
$$

4) if a daily dose $D_{\text {one/million }}$ corresponds to a cancer risk of 1 in $10^{6}$, the instantaneous dose $I D$ is $25,600 \times D_{\text {onemillion, }}$ the $D R C F$ is $\mathbf{0 . 0 1}$ (compound-specific data available to underpin this aberrant value, e.g. on the basis of PBPK-modelling), the $L D_{s 0}$ is $2,560,000 \times D_{\text {onemmilion }}$ (compound with low acute toxicity):

$$
\begin{aligned}
& \text { Risk }=10^{-6} \times I D \times\left(D_{\text {one/million }}\right)^{-1} \times 25,600^{-1} \times 100^{-1}= \\
& =10^{-6} \times 25,600 \times D_{\text {one/million }} \times\left(D_{\text {one/million }}\right)^{-1} \times 25,600^{-1} \times 100^{-1}=1 / 10^{8}
\end{aligned}
$$

5) if a daily dose $D_{\text {one/million }}$ corresponds to a cancer risk of 1 in $10^{6}$, the instantaneous dose $I D$ is $25,600 \times D_{\text {one/million }}$, the $D R C F$ is 10 , the $L D_{50}$ is $\mathbf{2 5 6} \times D_{\text {one/million }}$ (compound with high acute toxicity):

$$
\text { Risk }=0 \text { (No risk of cancer, because everyone is dead) }
$$




\section{List of abbreviations}

- $A D-m s$

Armitage-Doll multi-stage model

- $A U C$

Area Under the concentration-time Curve

- $B P$

benzo[a]pyrene

- $D B A$

dibenzanthracene

- $D B N$

dibutylnitrosamine

- DCM

dichloromethane

- DENA

diethylnitrosamine

- $D M B A$

7,12-dimethylbenz[a]anthracene

- DMNA

dimethylnitrosamine

- DOCM

dominant cataract mutation 
- $D R C F$

dose-rate correction factor

- DREF

dose-rate effectiveness factor

- $E N U$

ethylnitrosourea

- ID

instantaneous dose

- 3-MC

3-methylcholanthrene

- 20-MC

20-methylcholanthrene

- $\quad M N U$

methylnitrosourea

- $\quad M V K-2 s$

Moolgavkar-Venzon-Knudson 2-stage model

- $\quad$ NHMI

nitrosoheptamethyleneimine

- $\quad$ NNK

4-(methylnitrosamino)-1-(3-pyridyl)-1-butanone

- $O H-B B N$

N-butyl-N-(4-hydroxybutyl)nitrosamine

- $P A H$

polycyclic aromatic hydrocarbon

- $R S L M$

recessive specific locus mutation

- $S C E$

sister chromatid exchange

- URE

urethane (ethyl carbamate)

- $V C M$

vinyl chloride monomer

- VSD

virtually safe dose 
